Provided for non-commercial research and education use. Not for reproduction, distribution or commercial use.

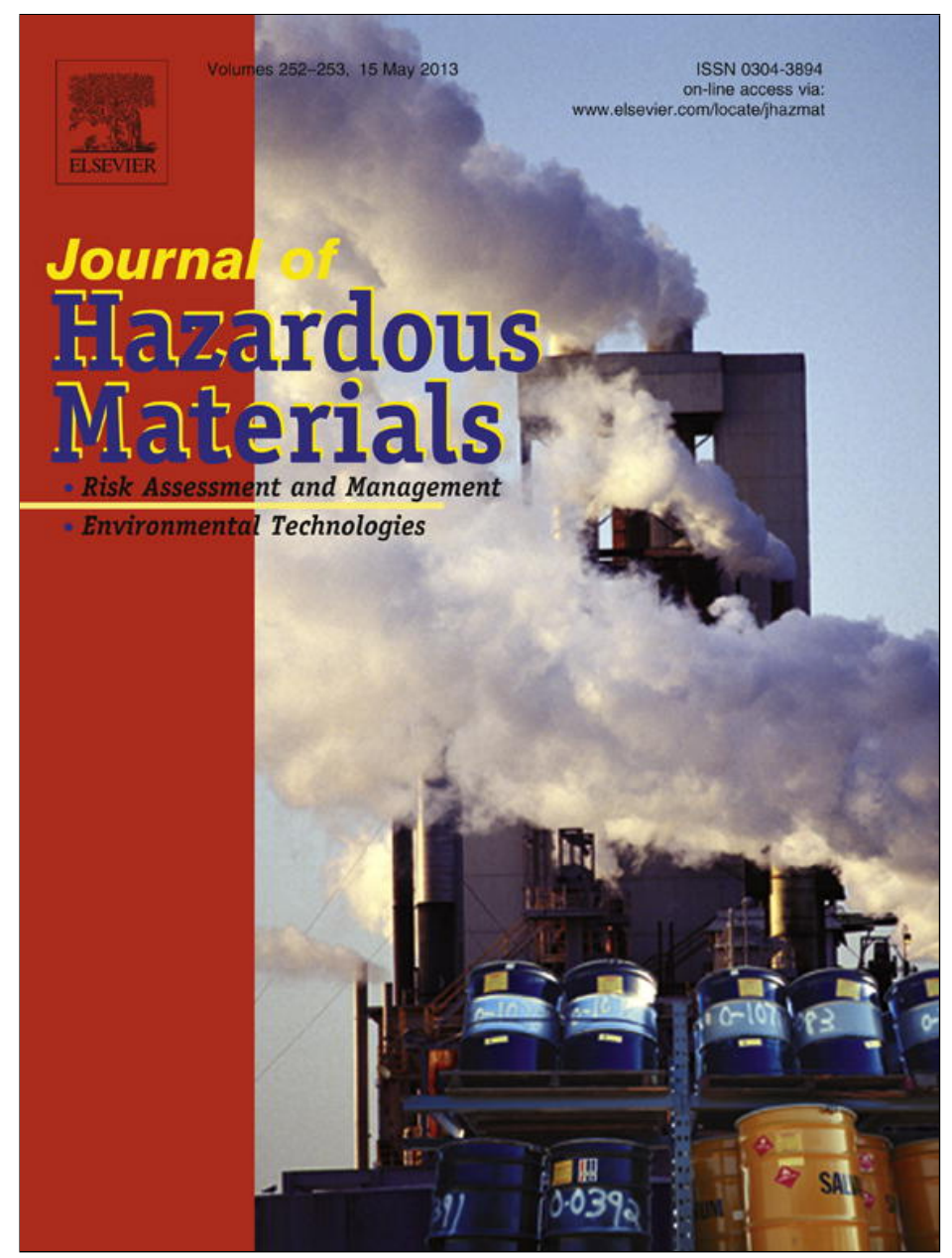

This article appeared in a journal published by Elsevier. The attached copy is furnished to the author for internal non-commercial research and education use, including for instruction at the authors institution and sharing with colleagues.

Other uses, including reproduction and distribution, or selling or licensing copies, or posting to personal, institutional or third party websites are prohibited.

In most cases authors are permitted to post their version of the article (e.g. in Word or Tex form) to their personal website or institutional repository. Authors requiring further information regarding Elsevier's archiving and manuscript policies are encouraged to visit:

http://www.elsevier.com/authorsrights 
Review

\title{
Organic xenobiotics removal in constructed wetlands, with emphasis on the importance of the support matrix
}

\author{
A.V. Dordio ${ }^{\mathrm{a}, \mathrm{b}, *}$, A.J.P. Carvalho ${ }^{\mathrm{a}, \mathrm{c}}$ \\ a Chemistry Department, University of Évora, Rua Romão Ramalho, 59, 7000-671 Évora, Portugal \\ b IMAR-Marine and Environmental Research Centre, University of Évora, Rua Romão Ramalho, 59, 7000-671 Évora, Portugal \\ c $C Q E$ - Évora Chemistry Centre, University of Évora, Rua Romão Ramalho, 59, 7000-671 Évora, Portugal
}

\section{H I G H L I G H T S}

- Substrate of wetlands plays a major role in removal of non-biodegradable pollutants.

- Optimization may be attempted by selection of materials with high sorption capacity.

- Clay minerals are generally efficient, widely available and cheap options.

- Agricultural wastes and by-products have been gaining increasing popularity.

- Available lab-scale assays must still be complemented with full-scale field assays.

\section{A R T I C L E I N F O}

\section{Article history:}

Received 8 December 2012

Received in revised form 7 February 2013

Accepted 4 March 2013

Available online 14 March 2013

\section{Keywords:}

Adsorption

Constructed wetland systems

Organic xenobiotics

Support matrix

Wastewater treatment

\begin{abstract}
A B S T R A C T
Constructed wetlands (CWs) are increasingly popular as an efficient and economical alternative to conventional wastewater treatment processes for removal, among other pollutants, of organic xenobiotics. In CWs, pollutants are removed through the concerted action of their components, whose contribution can be maximized by careful selection of those components. Specifically for non-biodegradable organic pollutants, the materials used as support matrix of CWs can play a major role through sorption phenomena. In this review the role played by such materials in CWs is examined with special focus on the amount of research that has been conducted to date on their sorption properties relatively to organic compounds. Where available, the reports on the utilization of some of those materials on pilot or full-scale CWs are also recognized. Greatest interest has been directed to cheaper and widely available materials. Among these, clays are generally regarded as efficient sorbents, but materials originated from agricultural wastes have also gained recent popularity. Most available studies are lab-scale batch sorption experiments, whereas assays performed in full-scale CWs are still scarce. However, the available lab-scale data points to an interesting potential of many of these materials for experimentation as support matrix of CWs targeted for organic xenobiotics removal.
\end{abstract}

(c) 2013 Elsevier B.V. All rights reserved.

\section{Contents}

1. Introduction.....

2. Constructed wetland systems

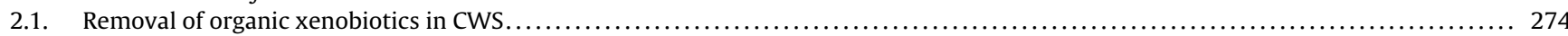

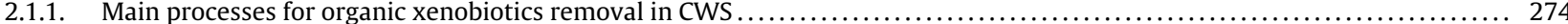

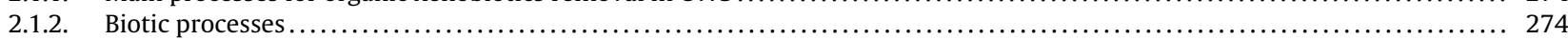

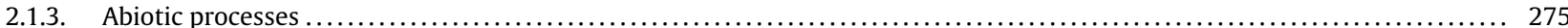

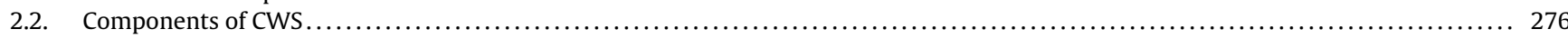

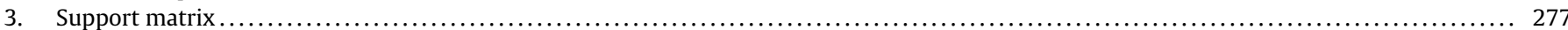

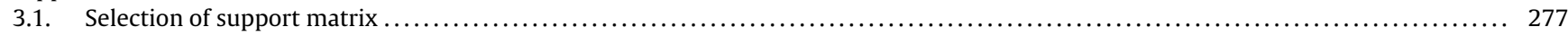

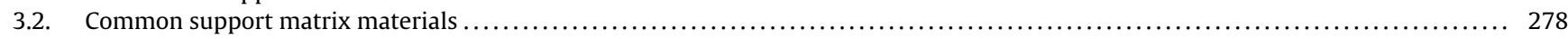

\footnotetext{
* Corresponding author at: Chemistry Department, University of Évora, Rua Romão Ramalho, 59, 7000-671 Évora, Portugal. Tel.: +351 266745343.

E-mail address: avbd@uevora.pt (A.V. Dordio).
} 


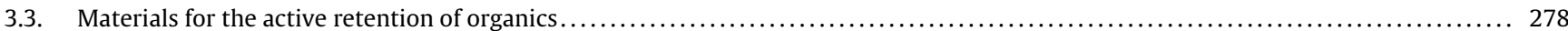

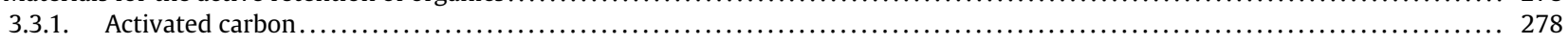

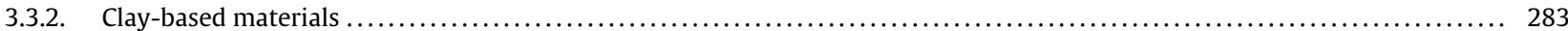

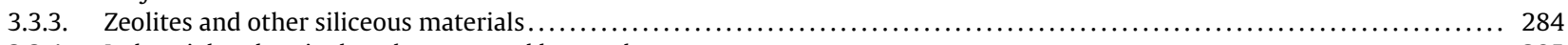

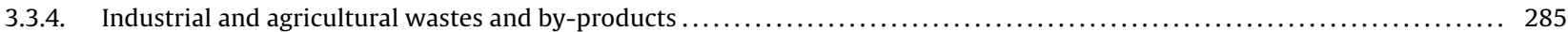

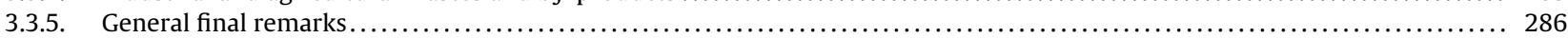

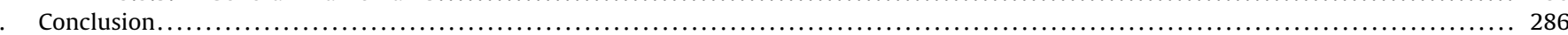

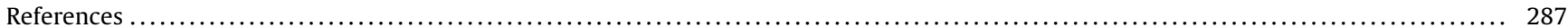

\section{Introduction}

The enormous and rapid development of chemical and agrochemical industries during the last century has resulted in the release of a large number of chemical compounds into the environment. In fact, a lot of different organic compounds are currently used in the daily life of human beings or result from human activities and many of these are frequently being detected in numerous environmental monitoring studies [1-9]. Pollution of soils and surface or ground waters occurs as a result of both point and diffuse sources, the improper use and disposal or accidental release of chemicals into the environment.

Aquatic ecosystems are especially vulnerable because water bodies are frequently used, directly or indirectly, as recipients of potentially toxic liquids and solids from domestic, agricultural and industrial wastes $[10,11]$. Some of the primary classes of pollutants which may accumulate in surface waters, ground water, soil and sediments are nutrients, organic contaminants (in particular xenobiotic compounds) and metals and metalloids.

Over the last decades increasing attention is being turned to a set of harmful organic chemicals mostly composed of xenobiotics [4-6]. Most of these pollutants are chemical substances that persist in the environment, can bioaccumulate throughout the food chain, and may be toxic to biotic communities, thus posing a risk to human health and the environment [5-7,12]. The list of such organic xenobiotics includes polycyclic aromatic hydrocarbons (PAHs), BTEX (benzene, toluene, ethylbenzene and xylene), petroleum hydrocarbons, polychlorinated biphenyls (PCBs), chlorinated solvents, explosives, dyes, pharmaceuticals and personal care products, phenolic compounds and pesticides [1,3-7,12]. Many of these substances can be transported over long distances, can be distributed into different compartments of the environment, and also undergo a variety of reactions and transformations [5]. Because of the many competing interactions, the fate of such pollutants is not easy to predict and, in many cases, their ecotoxicological effects are difficult to assess [5]. Nevertheless, possible synergistic effects that may potentiate their toxicity and the established possibility of longrange transport of these substances to regions where they have never been used or produced, with all the consequent threats they may pose to the environment of the whole globe, has motivated the international community to call, at several occasions, for urgent global actions to be taken with the aim of reducing the release of some of these chemicals $[13,14]$.

In recent years, numerous strategies and technologies have been developed for water and wastewater treatment or remediation of contaminated areas. Some of the advanced wastewater treatment technologies that have been evaluated for the removal of organic xenobiotics include advanced oxidative processes, activated carbon adsorption, membrane filtration and membrane bioreactors [7,15-21]. Despite the sometimes high removal efficiencies attained, most of these processes are not, however, widely used mainly for reasons of cost effectiveness [7,21-24]. Consequently, there is a growing need for alternative or complementary treatment processes for removing organic xenobiotics from soils, natural waters and wastewaters that have higher efficiencies at reasonable costs of operation/maintenance.

Phytotechnologies have been successfully used for removal of many organic xenobiotics from contaminated soils, waters and wastewaters [21,24-33]. This type of approach attempts to exploit the ability of plants to adsorb, uptake and concentrate or metabolize organic xenobiotics, as well as to release root exudates that enhance biotransformation and microbial degradation of those organics. The implementation of phytotechnologies such as constructed wetland systems (CWS) is becoming a popular option [33-39]. These systems are increasingly being used to provide a form of secondary, tertiary or quaternary treatment for wastewaters, and have already been used with success to remove several organic xenobiotics of various classes from contaminated waters [36-53].

In this paper we present a review on research work carried out over the latest years that can be useful for the task of finding suitable and more adequate materials to be used as the important component of CWS that is the support matrix. The focus is essentially centered on those systems especially targeted for the removal of organic xenobiotics from wastewaters. As will be explained further ahead, the support matrix is a crucial component of CWS whose careful selection can lead to significant enhancements of the efficiencies of these systems. These enhancements are especially relevant and long lasting if the CWS are used as tertiary or quaternary treatment systems, as is most often the case in the removal of non-biodegradable organics in domestic wastewaters. Given its importance, then, the composition of the support matrix is a primary point of CWS optimization.

Many aspects of the support matrix characteristics that are relevant for the CWS performance are considered in this review but sorptive properties generally have a prominent role and receive more coverage. In this regard, the vast majority of the studies were not conducted in full scale CWS but in simpler lab-scale batch adsorption assays, where the properties of the materials can be better characterized under controlled conditions. In many of those studies which are addressed in this review the focus is not exactly the utilization of the materials in CWS. However, when deciding the composition of the support matrix in the design of a CWS, the selection of materials may in part be based on the results of these works.

\section{Constructed wetland systems}

Constructed wetland systems can be defined as a designed and man-made structure composed of water saturated beds planted with emergent and/or submergent vegetation that simulates natural wetlands for human use and benefits [35,54-57].

Constructed wetlands can be classified into different types based on several of their characteristics. One classification system defines four types based on the dominant plant species [35,57-59]: (1) floating macrophytes (e.g. Eichhornia crassipes, Lemna minor), (2) floating-leaf macrophytes (e.g. Nymphea alba, Potamogeton gramineus), (3) submerged macrophytes (e.g. Littorella uniflora, Potamogeton crispus), and (4) emerged rooted macrophytes (e.g. Phragmites australis, Typha latifolia). Another common 
classification divides wetlands according to their hydrology [35,57,60]: (1) free water surface (FWS) wetlands or surface flow (SF) wetlands, (2) horizontal subsurface flow wetlands (HSSF), (3) vertical subsurface flow wetlands (VSSF), and (4) hybrid systems.

CWS have been used to treat a variety of wastewaters including urban runoff, municipal, industrial and agricultural wastewaters [35-37,50,55-58,60-63]. In fact, for a long time natural wetlands have been credited with a capacity to depurate the waters that inundated such areas. CWS take advantage of many of the same processes that occur in natural wetlands, but do so within a more controlled environment and can be optimized to potentially attain greater efficiencies.

In the past, CWS have been used mainly as wastewater treatment alternatives or complementary to the conventional treatment for domestic wastewaters of small communities. Thus, CWS have been mostly applied in the removal of bulk wastewater pollutants such as suspended solids, organic matter, excess of nutrients and pathogens.

More recently, CWS applications for dealing with more specific pollutants, such as some types of organic pollutants, especially those which are more recalcitrant to the conventional processes used in most wastewater treatment plants (WWTPs), have been meeting a larger interest and have been the subject of an increasing number of studies. In many of such studies, CWS have been proving to be efficient and cost-effective solutions for the removal of some organic xenobiotics such as pesticides, dyes, explosives, phenolic compounds, petroleum hydrocarbons, pharmaceuticals and hormones [36-38,40,42-52,64-71].

Ultimately, the optimization of CWS for the removal of more specific target compounds requires a basic knowledge of the processes involved in the removal of the pollutants and the interactions between those and the CWS components. New trends in CWS research are moving towards the study of such processes and interactions, and focus on the selection and optimization of the CWS components for more specific applications.

\subsection{Removal of organic xenobiotics in CWS}

The exact pathways for organic xenobiotics removal in CWS are not yet currently known in much detail. Despite being classified under a common designation, organic xenobiotics comprise a set of chemical compounds which span a wide variety of characteristics and this class is, in fact, formed by several largely unrelated families of substances. Therefore, it is not surprising to realize that many very diverse processes are responsible for their removal. The degree to which each process will contribute to the overall removal of the organic xenobiotics from contaminated waters in CWS is in turn dependent on the physico-chemical properties of these compounds (e.g., molecular structure, polarity, $\mathrm{p} K_{\mathrm{a}}$, water solubility, $\log K_{\text {ow }}$, volatility and chemical stability), characteristics of the support matrix (e.g., point of zero charge (pzc), organic matter content, mineralogical composition, specific surface area), the plant species, microbial populations, wastewater characteristics (e.g., pH, dissolved organic matter (DOM), electrolytes composition) as well as other environmental conditions (e.g., temperature, moisture, nutrient availability) [24,72].

A comprehensive description of organic xenobiotics removal processes in CWS is, thus, not an easy task to accomplish and these wastewater treatment systems have been (and, to some extent, still are) frequently operated as "black boxes". In the past, much of the design of CWS has been done with little knowledge of (or consideration for) the roles played by each component and how their effects could be enhanced and optimized. However, over the most recent years some accumulated knowledge has been increasingly applied in the construction and operation of new systems, which results in a much greater variety of plant species, support matrix materials and constructed wetland designs being seen, studied and introduced in newly set up CWS $[35,42,43,58,60,73-85]$. The goals of the target contaminants to remove in those CWS have also become increasingly more ambitious.

Major design parameters, removal mechanisms and treatment performances have been studied and reviewed by several researchers [35-37,56-58,60-62,73,86,87].

\subsubsection{Main processes for organic xenobiotics removal in CWS}

Organic xenobiotics removal by CWS involves several interdependent processes which, under one of the possible classification criteria, may be distinguished as biotic (carried out by living organisms such as plants and microorganisms) or abiotic (physical or chemical) processes. These processes are essentially the same occurring in natural wetlands and also identical to those responsible for the fate of xenobiotics in the environment [72]. The way in which CWS differ from a natural system such as a natural wetland is that the effects of some of these processes can be optimized in the controlled environment of a CWS in order to maximize the removal of pollutants (or, at least, of a specific set of contaminants). With that aim, a basic understanding of how these processes operate in wetlands is extremely helpful for assessing the potential applications, benefits and limitations of CWS.

\subsubsection{Biotic processes}

CWS are essentially biological systems, considering that the biotic components (the wetland vegetation and the microbial populations) are two of the major components of CWS. Hence, biological processes naturally play an important role in the removal of many pollutants (including organic xenobiotics) by these systems.

Microorganisms usually play the main role in the transformation and mineralization of nutrients and organic pollutants $[35,58,82]$. In particular with respect to the removal of organic xenobiotics, although microorganisms may also provide a measurable amount of uptake and storage, it is their set of metabolic processes that plays the most significant role in the decomposition of these compounds (or at least the ones that are biodegradable) through the transformation of complex molecules into simpler ones. Biodegradation of organic chemicals is associated primarily with heterotrophic bacteria and certain autotrophic bacteria, fungi including basidiomycetes and yeasts, and specific protozoa [35,72].

Biodegradation can occur under both aerobic and anaerobic conditions. Depending on the oxygen input by macrophytes and the availability of other electron acceptors, the contaminants in the wastewater can be metabolized in various ways. Highly reduced conditions are favorable for the degradation of some chlorinated hydrocarbons [72].

Biodegradation of benzene, octane, toluene, PAHs derived from petroleum, and most other manufactured organic compounds is enhanced under aerobic condition, and PCBs degrade faster under moderately reducing conditions [72].

Microbial transformations can involve more than one type of mechanism and, under different conditions, several products can be derived from the same initial compound depending on the environmental conditions. Additionally, transformations can be mediated by one organism or through combined effects of several organisms $[72,82]$.

The efficiency and rate of organic xenobiotic degradation and the extent of microbial growth during degradation is highly variable for different types of organic compounds and heavily influenced by the xenobiotic chemical structure as well [88]. Structurally simple compounds with high water solubility and low adsorptivity are usually more similar to the naturally occurring substances which are usually used as energy sources by the microorganisms and are easily degraded. In contrast, xenobiotics with chemical structures very different from the naturally occurring compounds 
are often degraded slowly since microorganisms do not possess suitable degrading genes. In these cases degradation by nonspecific enzymes may still occur but at a slower rate by non-specific reactions which do not support microbial growth (co-metabolism) [89].

Xenobiotic degradation by the microorganisms is also strongly influenced by the support medium where the microbial populations grow. Temperature, $\mathrm{pH}$, oxygen, presence of toxic substances and nutrients available within the CWS are expected to play a very important role in the removal efficiency $[72,81-83,90]$.

Microorganisms with the ability to degrade a wide variety of compounds, like benzene, phenol, naphthalene, atrazine, nitroaromatics, biphenyls, PCBs and chlorobenzoates, have been isolated and characterized $[35,72,88]$. Although simple aromatic compounds are biodegradable by a variety of degradative pathways, their halogenated counterparts are more resistant to bacterial attacks and often need the evolution of novel pathways [88]. In particular, the presence of chlorine atoms in the aromatic center is known to greatly retard the rate of degradation.

Plants also have a relevant role in the biotic processes of organics removal in CWS, involving a number of biological processes of which many details still remain to be fully understood. Depending on the pollutant properties, organics may be degraded in the roots zone through the plant stimulation of microbial activity (phytostimulation or rhizodegradation) or by direct uptake by the plant, followed by degradation within their tissues via their own enzymatic activities (phytodegradation) and sequestration (in vacuoles or bound to insoluble cellular structures) or volatilization [24-28,73,91-94].

Many organic pollutants can be readily taken up by plants but, as consequence of many of them being xenobiotic, there are no specific transporters for these compounds in plant membranes. Therefore, organic xenobiotics move into and within plant tissues via diffusion (passive uptake) through cell walls and membranes $[27,28]$. The rate of uptake and translocation within the plants is highly dependent on the water solubility and hydrophobicity of the compounds (as expressed by the $\log K_{\text {ow }}$ ). A moderate hydrophobicity, characterized by a $\log K_{\text {ow }}$ in the range of $0.5-3.5$, is generally considered to be optimal for allowing the organic substance to move easily between the lipidic and the aqueous phases, without being irreversibly trapped in any of each $[27,28,95]$. Such group of compounds includes most chlorinated solvents, BTEX, many pesticides, and short-chain aliphatic chemicals. Alternatively, chemicals that are too hydrophobic $\left(\log K_{\mathrm{ow}}>3.5\right)$ may be candidates for phytostabilization and/or rhizosphere bioremediation by virtue of their long residence times in the roots zone $[27,28]$.

Metabolism of pesticides has already been extensively studied for many years $[29,96,97]$ while the metabolism of nonagricultural xenobiotics such as trichloroethylene (TCE), TNT, glyceroltrinitrate (GTN), PAHs, PCBs, pharmaceuticals and other chlorinated compounds has also been dealt with more recently [28-30,98-101]. It was shown that most of these compounds are metabolized but only a few chemicals appear to be fully mineralized. It may be a matter of concern that some of these metabolites produced by plants may be more toxic than the original compounds, thus making plants less attractive compared with microorganisms, which totally degrade organic pollutants [25].

The effect of stimulating the development of microbial populations and enhancing their activity is another role of major importance played by plants. In fact, larger microbial populations are sustained in the rhizosphere than in the bulk soil by a variety of products secreted by plants (exudates, mucigels, dead cell material, etc.) $[28,60,82]$ which evidences how important these interactions between CWS components can be. Some plant exudates may also provide catalytic processes that can contribute to the degradation of compounds, in addition to the microbial processes. Both these phytostimulation or rhizodegradation processes are enhanced by large and dense root systems, which consequently have higher levels of degrading enzymes [28], and, hence, these are favorable characteristics in plants used for phytoremediation. Classes of organic compounds that are more rapidly degraded in the rhizosphere than in bulk soil include PAHs, total petroleum hydrocarbons, chlorinated pesticides as well as other chlorinated compounds like PCBs, explosives such as TNT and RDX, organophosphate insecticides, and surfactants [28,102,103].

The capacity of some plant species to release oxygen around their roots tips has a crucial role of favoring the development of aerobic microorganisms and their generally more efficient degradative processes. In some cases it can also promote oxidative chemical processes [58] and, thus, the most sensitive areas on the roots surface are protected by this oxidative film from being damaged by toxic wastewater components in the anoxic, usually extremely reduced, rhizosphere [60].

\subsubsection{Abiotic processes}

Abiotic processes involved in the removal of pollutants from wastewater comprise a wide range of physical and chemical phenomena. The most important process of this kind occurring in CWS, at the surface of plants roots and of the solid media (in those systems where there is a substrate, e.g. SSF-CW) or at biofilms developed on those surfaces, is sorption, resulting in a short-term retention or long-term immobilization of contaminants. In addition to physical sorption, ion exchange involving mineral components of the solid matrix can also contribute to the removal of some particular classes of pollutants. The occurrence of this type of processes will be strongly influenced by the type of materials which compose the substrate of the CWS bed. The chemical characteristics of this solid matrix determines its capacity to sorb pollutants [72] but retention in abiotic components is also a function of several characteristics of the wastewater (such as its DOM content, $\mathrm{pH}$ and electrolytes composition) as well as of the pollutant itself (e.g. $\mathrm{p} K_{\mathrm{a}}$, solubility, $\log K_{\mathrm{ow}}$, etc.). The extent of sorption effects can, however, be limited in time as the surfaces become saturated with the adsorbates. Saturation of the sorption capacity of the support matrix will depend on the amounts of the substances present in the liquid and the overall complexity of the solution composition (i.e. the chemical variety of substances). In the case of pre-treated wastewater (when the CWS is used in a tertiary or quaternary stage) both the amounts and variety of the pollutants have been significantly reduced after the previous treatment stages, which may allow for a longer life-time of the adsorbent media. For the efficiency of sorption processes a good hydraulic conductivity of the support matrix is also crucial since the occurrence of overland flows and preferential channeling must be prevented and a good, uniform contact of the wastewater with the CWS media must be assured $[35,57]$. Other important effect that may impact the performance of sorption processes is the natural development of biofilms over the media's surface.

Other common abiotic processes such as hydrolysis, photodegradation, redox reactions and volatilization can also contribute, in varied extents, to the removal of some particular classes of compounds, depending on their specific properties. However, with the exception of sorption, abiotic processes are not, in general, major removal processes for most organic compounds because either the conditions in CWS or the properties of the compounds are not adequate. For example, photodegradation can only be significant in SF systems (see beginning of Section 2), provided that plant density is not too high (such that it does not cause too much shade over the water surface) and only for compounds that are photosensitive. In SSF systems photodegradation does not occur in appreciable extent as the water level is below the solid matrix surface and, therefore, exposure of the pollutants to sunlight is very limited in this type of systems. The process of volatilization is also of 
modest importance as most organic xenobiotics have low volatility. Where CWS are used as a tertiary treatment stage after conventional secondary treatment in a WWTP, organic compounds do not suffer, in most cases, appreciable hydrolysis either, as they have already been subjected to such type of processes during secondary treatment stage. Therefore, the organic xenobiotics present in CWS influents are those that have resisted such hydrolysis processes or they are the transformation products of those substances that did not resist it.

\subsection{Components of CWS}

A CWS is basically composed of three main components: the support matrix (the bed substrate), the vegetation and microbial populations. It is by the concerted action of all these interdependent components (through the variety of chemical, physical and biological processes that have been enumerated and described before) that the depuration of wastewaters can be achieved in these wastewater treatment systems.

Plants play several important roles in a CWS with both a direct and indirect influence in the global treatment efficiency and, therefore, a careful selection of the more suitable species to use in each system is an important design decision. Some of those roles (including the contribution of the major processes provided by plants as described in Section 2.1.2) are [24,35,58,59,87]:

- to provide the filtration of large debris;

- to supply surface area for development of microorganisms and to stimulate their growth (aided by exudates released through the roots);

- to promote hydraulic conductivity of the support matrix (extensive roots and rhizomes help prevent clogging);

- to transport and release oxygen through the roots (which increases aerobic degradation and nitrification);

- and to diminish the wastewater pollutants load (by adsorption, phytodegradation and/or uptake of nutrients and organic compounds).

For the purpose of phytoremediation, one of the primary criteria in the selection of plant species is their tolerance to the pollutants toxicity and the extent of their role in lowering the pollutants concentrations in water through the variety of the processes which have already been described.

When intended to be used in CWS other desirable characteristics of plants are [35,56,58,104]: ecological adaptability (the chosen plants should pose no risk to the natural ecosystem surrounding); tolerance to local conditions in terms of climate, pests and diseases; tolerance to the hypertrophic water-logged conditions of wetlands; ready propagation, rapid establishment and growth, good root system development and perennial duration rather than annual. Other additional objectives (such as ecological, aesthetic, recreational, and economic) of wetland developments may also affect the choice of the plants [58,104].

In addition to species selection, other aspects related with the CWS design, such as plant density and layout of the specimens (e.g. the way specimens of different species may be intermixed when planted in the beds), may be important and probably should be carefully planned as their influence may range from subtle differences in the system behavior to more pronounced impacts in the overall efficiency [35,77]. In particular, the cycles of vegetative activity of some species in addition to variations of climate conditions may lead to significant seasonal changes in the system efficiency, which in some cases may be mitigated by using polycultures of vegetation [35].

The vegetation of a CWS is usually formed exclusively by macrophytes (the type of plants that are more common in natural wetlands). Aquatic macrophytes seem to be especially resistant to the toxicity of a great variety of organic pollutants at concentrations normally encountered in typical wastewater compositions. In addition, numerous studies have shown the capability of many macrophyte species to reduce the aqueous concentrations of various organic xenobiotics such as explosives [40,105-107], petroleum hydrocarbons [36], pesticides [108-110] and more recently on some pharmaceuticals [100,111-115].

Several different species of macrophytes can be used in CWS depending on the type of CWS design (SF or SSF) and its mode of operation (continuous or batch), loading rate, wastewater characteristics and environmental conditions. However, despite the fact that the dominant species of macrophyte varies locally, the most commonly used in SSF-CWS in temperate zones are the reeds (Phragmites spp.) and the cattails (Typha spp.) [35,56,57,104,116]. In Europe, Phragmites are the preferred plants for these systems. Phragmites have several advantages since it is a fast growing hardy plant and is not a food source for animals or birds [56]. However, in some parts of the U.S. the use of Phragmites is not permitted because it is an aggressive plant and there are concerns that it might infest natural wetlands. In these cases cattails or bulrush (Scirpus spp.) can be used [116].

The role of plants in the direct degradation and uptake of organic pollutants, in particular xenobiotics of anthropogenic origin, is not as important as the one provided by the action of microorganisms, but in many cases it may still represent a very significant contribution. Notwithstanding, the major role in the biodegradation of many of these contaminants is unquestionably played by microorganisms (through their metabolic transformations) which consequently form a vital part of CWS [58]. Populations of microorganisms develop naturally in CWS and are exposed to some similar factors as those affecting their development in WWTPs. These microbial communities are very diverse and one can find an array of bacteria, fungi, protozoa, algae, etc., among the microorganisms that thrive in wetlands, which provide adequate environmental conditions for their growth and development but whose characteristics are also pronouncedly influenced by the type of vegetation and the support matrix materials [35,58,81-83]. The characteristics of these microbial populations can additionally be modified by inoculation of the CWS with strains that are more suitable for the purpose of the system. This diversity potentiates the capacity of microbial biofilms to carry through an assortment of microbial activities which are essential in the performance of a CWS. In particular, a diverse mixture of both aerobic and anaerobic bacteria is useful in the degradation of organic matter, including some organic xenobiotics. Therefore, there may be some interest in the characterization of microbial communities in CWS. Unfortunately, the information available up to date on the microbial communities developing in different solid media and on the influences due to the wetland vegetation is still rather limited.

One feature of the action of the biotic components (microorganisms and plants) is that their activities typically go through high and low cycles throughout the year and therefore they introduce undesirable seasonal variations in the CWS performance. To some extent, this may possibly be smoothed by the action of some processes occurring at the abiotic component (support matrix).

The primary function of the support matrix in a CWS, just as the soil in natural wetlands, is to provide a physical support where the plant root systems can be anchored and to present a surface for the attachment and growth of microorganisms [57,58]. In addition, plant roots and microorganisms can find in this component their supplies of water, air and nutrients as well as some moderation of environmental conditions which can affect their development, such as temperature or $\mathrm{pH}$. The matrix should also allow an even infiltration and flow of the wastewater through the system. Beyond this supportive role, the matrix acts as a filter medium that will trap 
particulate pollutants and sorb some types of dissolved pollutants. Some mineral materials also have ion exchange capacity which may provide for some ability to retain polar or ionic compounds.

In practice, every CWS should be constructed with a careful selection of the materials used as the support matrix, the type of vegetation and microbial population, which may prove an important step in the optimization of the constructed wetland performance.

\section{Support matrix}

The support matrix is a vital component in a subsurface flow (SSF) CWS as it provides the link between all the components and the main treatment processes occurring within the system. The support matrix may be composed of several different materials, each of which having its own particular characteristics such as granulometric and hydraulic properties, mineralogical composition, acid-base and surface charge properties, content of organic matter, sorptive properties, among others. These properties will influence the development of the biota which the substrate provides support for. In fact, it has been observed that some particular materials seem to be preferable media for some plant species and microorganisms strains [81-83,90]. On the other hand, the development and activity of the biotic elements may over time affect and modify the support matrix characteristics. The chemical properties of the materials may determine the type and strength of the interactions between the support matrix and the pollutant molecules at the surfaces of the solids. For different types of support matrices, the correspondingly different partitioning of the pollutant between the water and the solids compartments will influence the pollutant behavior in the CWS and the processes to which it will be submitted.

When designing a new wastewater treatment wetland system, the stage of selecting the support matrix materials to be used in the beds is an opportunity to optimize and significantly enhance the solid matrix role in the removal of the pollutants, which may contribute to an overall improvement of the treatment system efficiency. For example, sorption processes are usually seen as only providing a short-time retention of pollutants until sorption capacity of the support matrix becomes saturated. However, it has been observed $[38,42,117]$ that these processes may be important to moderate the seasonal variations of the efficiency of a CWS that are due to the variations of the biotic components activities, thereby providing for a more stable performance of the systems throughout the whole year.

\subsection{Selection of support matrix}

The choice of the support matrix materials to be used in any given system should be determined in terms of their physical and chemical characteristics. Chemical properties which are determined by the materials compositions (e.g. the development of a surface charge due to acid-base properties) as well as physical characteristics (e.g. particle size distributions, porosity, effective particle size and hydraulic conductivity) are all important factors that affect the system performance $[35,57,79,80]$. Given the interdependences between all CWS components (e.g., the influence that the support matrix may have on the development of plants and microorganisms; the $\mathrm{pH}$ changes during anaerobic biodegradation processes that may chemically affect/degrade some materials) the selection of this component should not be made independently of the selections of the other two components. Instead, the design of the whole system should be approached as an integration of all the parts, in view of the synergistic effects that can be created by the set of all components together.
The mechanical and chemical resistance of the materials composing the support matrix is a fundamental characteristic as this component should withstand the conditions of operation (flow and chemical composition of the wastewater) without significant degradation of its main properties. In addition, it should not release substances that may be a source of toxicity for the biotic components or that may ultimately contaminate the treated wastewater.

The flow of liquid through the wetland bed depends on the hydraulic gradient along it as well as the hydraulic conductivity, size and porosity of the materials used. Hydraulic conductivity is a fundamental characteristic of the support matrix as it should allow for an even distribution of the inlet flow and collection of the outlet flow. A low hydraulic conductivity will result in short-circuit flow of the wastewater between inlet and outlet over the wetland surface or the development of channeling which both contribute to a poor contact of the wastewater with the system and severely reduces the effectiveness of the system [118]. As a general rule, successful operation requires hydraulic conductivities of approximately $10^{-3}$ to $10^{-4} \mathrm{~m} \mathrm{~s}^{-1}$ [56-58].

The bed porosity (defined as the ratio of pore water volume to the total volume; typically the porosity of a coarse sand or gravel media is in the range $30-45 \%[35,56,58,116])$ provides the space for wastewater treatment processes (physicochemical as well as biological) to occur. In addition, air-filled porosity may be involved in gas exchange processes which are necessary to aerate the rhizosphere (in well-drained soils, oxygen enters the soil and carbon dioxide leaves the soil through the air-filled pores, whereas in flooded systems, the majority of gas exchange occurs through the plants as the effective pore space for the movement of oxygen and other gases within the solid matrix is inversely related to the percent of water filled pores). Oxygen diffusion and, consequently, the support matrix oxygen content affect both plants and microbial growth $[35,57,119]$.

Pore sizes distributions and air-water relationships are influenced by the particles sizes of the support matrix materials. Generally, as particle sizes get larger, the void size increases but the void ratio (i.e., total volume of voids versus the total volume of solid and voids) decreases.

Porosity also significantly influences hydraulic conductivity, with materials of higher porosity typically having a higher hydraulic conductivity (more open area for the flow of water), although in some cases a simple relationship may not be easily established between the two properties [35,57].

The sizes of the support matrix particles have a determining effect on both the hydraulic characteristics and the porosity of the media. Particle size fractions in the range of $0-30 \mathrm{~mm}$ are normally used depending on the type of material [57]; for example, gravel sizes are typically within $0-12 \mathrm{~mm}$ [57,58]. Often additional criteria must be complied with, such as, for instance, the requirement that $d_{10}$ (effective particle size) is greater than $0.3 \mathrm{~mm}$ or that $d_{60} / d_{10}$ (uniformity coefficient; $\mathrm{d}_{60}$ and $\mathrm{d}_{10}$ represent the particle diameter for which $60 \%$ and $10 \%$ of the sample mass, respectively, are finer than a sieve mesh of that size) is larger than 4 [57].

For the development of vegetation and microbial communities, the physicochemical properties of the support matrix in terms of $\mathrm{pH}$, porosity, surface area, availability of nutrients and organic matter content is also determinant. Organic soils or carbon rich support materials (such as compost for example) can promote microbially mediated processes by providing the system with the necessary source of carbon. Likewise, porous matrices may enhance the contribution of microorganisms by providing a larger surface area for treatment contact and biofilm development. The nature and activity of the biotic CWS components is also strongly correlated to the support matrix $\mathrm{pH}$, which has a particularly profound effect on the microbial community composition and the development of plants. Different gradients of redox, nutrients availability, and 
environmental conditions, such as $\mathrm{pH}$ and temperature create variable niches throughout the wetland systems, in which different biochemical processes take place which can be determinant for the treatment efficiency [81-83,90].

The chemical characteristics of the support matrix also determine its capacity to retain pollutants by sorption or ion exchange $[119,120]$. Sorption of non-polar organic pollutants onto suspended solids and onto the support matrix can in many cases be described as a water-lipid partitioning process, whereby the substance is partitioned between the water and the organic matter fraction in the solid phase [119]. Organic matter rich materials such as some types of soil, compost and biosorbent materials such as agricultural wastes are suitable for the retention of this type of pollutants (provided that the potential for release of significant amounts of DOM is mitigated). On the other hand, sorption of polar or ionic pollutants is dominated by electrostatic interactions and ion exchange phenomena. Materials with such characteristics can be found among several types of clays [36,121-125]. The large majority of organic xenobiotic pollutants are non-polar, although some particular classes like most pharmaceuticals are polar or ionizable [119].

The rate and extent of these processes are reported to be influenced by several factors, such as nature and amount of clays, nature and amount of soil organic matter, periods of submergence and drying, presence of vegetation and the development of biofilms.

Ultimately, cost is a fundamental factor determining the selection of the materials for a support matrix. The local availability, ease of access and lack of expensive treatment are the main decisive conditions that influence the price of most materials.

\subsection{Common support matrix materials}

A wide variety of materials have been used as support matrices for CWS, the most frequent choices being gravel, crushed rock, sand (usually river sand), gravel/sand mixtures and local soil $[35,56,57,116]$. Some characteristics of a few of the most common materials used as CWS support matrix are presented in Table 1.

Traditionally, CWS have been constructed with soil as growth media for the plants. However, systems with fine sand and soil based support matrices in general will have low hydraulic conductivities, with all the associated problems that have been mentioned before. Coarse sand and gravel based support matrices, on the other hand, display higher conductivities (Table 1). Therefore, presently adopted design guidelines are based on gravel or coarse sand and in some cases intermittently loaded vertical flow beds instead of horizontal flow beds $[55,116]$. Mixtures of sand with gravel have also been shown to produce substrates with appropriate hydraulic properties for CWS [60].

These more traditional materials, however, simply act as filters for retaining larger particles and as support for development of the biota. Their capacity to retain pollutant molecules by sorption is, in general, negligible. Their substitution for other materials, which may play a more active role in the removal of the pollutants especially through the contribution of sorption processes, has been increasingly attempted and reported by many studies published over the latest years.

\subsection{Materials for the active retention of organics}

Recently, the application of CWS for treating increasingly more specific targets, such as xenobiotic organic compounds, has spurred numerous attempts to optimize the contribution of each component to the overall pollutants removal. Specifically in the selection of the support matrix materials, studies should allow to distinguish those that are inert to the target pollutant from those that effectively interact with it. Then, it may be possible to reserve a more active role for the substrate component than merely to serve as support for the development of vegetation and microbial populations.

Pioneering work on the CWS optimization of the support matrix component was initially targeted at the removal of nutrients such as phosphorus. Natural materials as well as various artificial media were tested in order to improve phosphorus removal in CWS, e.g. factory made light-weight expanded clay aggregates (LECA) [79,126-128], shale [128,129], crushed marble [79,130], diatomaceous earth, vermiculite and calcite [79], zeolites and limestone [128,131], furnace slag [132] and fly ash [132]. The vast variety of materials that have been studied for P-removal in CWS has already been the subject of several review works [133-136]. It has generally been found that many of the tested materials have the potential to enhance P-removal in CWS, although sorption capacity saturation after some period of the bed's operation has been identified as a major problem.

Subsequent work has been extended to several other types of pollutants, in particular for the removal of recalcitrant organics for which biodegradation does not present an effective solution. Numerous studies on the sorption properties of varied types of materials (common natural mineral and organic materials, modified or processed natural materials and newly developed synthetic ones) have guided the selection of those with appropriate chemical characteristics.

A variety of materials that have been studied relatively to their capacity to sorb organics, is presented in Table 2. Following, an overview is given of the most representative types of materials that have been evaluated especially for sorption of organic pollutants from aqueous media. Most work has consisted of batch sorption studies which only give a preliminary indication of the efficiency (and, in some cases, also the kinetics) of the sorption processes, but a few experiments have also been carried out in CWS beds. In the latter study cases, the successful experiments may give an indication of the compatibility of the materials with the development and sustainability of the biotic CWS components.

\subsubsection{Activated carbon}

Activated carbon is one of the oldest, most popular and widely used adsorbents [137-139]. Its capacity and versatility is mainly due to its porous texture that provides it with a large surface area, its controllable pore structure and its thermo-stability [140]. Its chemical nature can also be easily modified by chemical treatment in order to enhance its properties.

Table 1

Characteristics of common support matrix materials $[55,58]$.

\begin{tabular}{lccr}
\hline Substrate type & Effective size, $d_{10}(\mathrm{~mm})$ & Porosity $(\%)$ & Hydraulic conductivity, $K_{\mathrm{s}}\left(\mathrm{m} \mathrm{s} \mathrm{s}^{-1}\right)$ \\
\hline Coarse sand & 2 & 32 & 35 \\
Gravelly sand & 8 & 38 & $5.8 \times 10^{-2}$ \\
Fine gravel & 16 & 40 & $8.7 \times 10^{-2}$ \\
Medium gravel & 32 & 45 & $11.6 \times 10^{-2}$ \\
Coarse rock & 128 & $115.7 \times 10^{-2}$ \\
\hline
\end{tabular}


Table 2

Studies of compounds sorption by several natural, modified and synthetic materials and industrial and agricultural wastes and by-products.

\begin{tabular}{|c|c|c|c|c|}
\hline Material $^{\mathrm{a}}$ & Pollutants & $\begin{array}{l}\text { Study type (assay } \\
\text { type/mixture } \\
\text { type/solvent) }\end{array}$ & Removal efficiency/sorption capacity & Reference \\
\hline \multicolumn{5}{|l|}{ Activated carbon (AC) } \\
\hline Activated carbon & Bisphenol A & BSS/SCS/PW & $382.12-432.34 \mathrm{mg} \mathrm{g}^{-1}$ & {$[161]$} \\
\hline$"$ & BTEX & BSS/SCS/PW & $215.71-275.74 \mathrm{mg} \mathrm{g}^{-1}$ & {$[160]$} \\
\hline$"$ & Dyes & $\mathrm{BSS} / \mathrm{SCS} / \mathrm{PW}$ & $0.11-0.27 \mathrm{mmol} \mathrm{g}^{-1}$ & {$[143]$} \\
\hline$"$ & Dyes & $\begin{array}{l}\mathrm{BSS} / \mathrm{SCS} / \mathrm{PW} \text { and } \\
\mathrm{CS} / \mathrm{SCS} / \mathrm{PW}\end{array}$ & $198-412 \mathrm{mg} \mathrm{g}^{-1}$ & [141] \\
\hline$"$ & Dyes & $\mathrm{BSS} / \mathrm{SCS} / \mathrm{PW}$ & $\begin{array}{l}\sim 90 \% \\
53 \mu \mathrm{molg}^{-1}(313 \mathrm{~K})\end{array}$ & [144] \\
\hline$"$ & Dyes & BSS/MCS/PW & $159-309.2 \mathrm{mg} \mathrm{g}^{-1}$ & {$[146]$} \\
\hline$"$ & Dyes & BSS/SCS/PW & $0.3-8 \mathrm{mmol} \mathrm{g}^{-1}$ & {$[145]$} \\
\hline$"$ & Explosives & $\mathrm{CS} / \mathrm{SCS} / \mathrm{PW}$ & $0.080-0.196 \mathrm{mg} \mathrm{g}^{-1}$ & {$[159]$} \\
\hline$"$ & Pesticides & $\mathrm{BSS} / \mathrm{SCS} / \mathrm{PW}$ & $163.9 \mathrm{mg} \mathrm{g}^{-1}$ & {$[153]$} \\
\hline$"$ & Pesticides & $\mathrm{BSS} / \mathrm{SCS} / \mathrm{PW}$ & $0.186 \mathrm{mg} \mathrm{g}^{-1}$ & {$[154]$} \\
\hline$"$ & Pesticides & $\mathrm{BSS} / \mathrm{SCS} / \mathrm{PW}$ & $909.1 \mathrm{mg} \mathrm{g}^{-1}$ & {$[152]$} \\
\hline$"$ & Pesticides & $\mathrm{BSS} / \mathrm{SCS} / \mathrm{PW}$ & $96.15-181.82 \mathrm{mg} \mathrm{g}^{-1}$ & {$[151]$} \\
\hline$"$ & Pesticides & $\mathrm{BSS} / \mathrm{SCS} / \mathrm{PW}$ & $156.3 \mathrm{mgg} \mathrm{g}^{-1}(303 \mathrm{~K})$ & {$[150]$} \\
\hline$"$ & Pharmaceuticals & BSS/SCS/PW & $28.5 \mathrm{mg} \mathrm{g}^{-1}$ & {$[157]$} \\
\hline$"$ & Pharmaceuticals & BSS/SCS/PW & $236-354 \mathrm{mg} \mathrm{g}^{-1}$ & {$[158]$} \\
\hline$"$ & Pharmaceuticals & $\mathrm{BSS} / \mathrm{SCS} / \mathrm{PW}$ & $139.2-393.4 \mathrm{mg} \mathrm{g}^{-1}(298 \mathrm{~K})$ & {$[155]$} \\
\hline$"$ & Pharmaceuticals & $\begin{array}{l}\mathrm{BSS} / \mathrm{SCS} / 1: 9 \\
\text { methanol:water }\end{array}$ & $139-295 \mathrm{mg} \mathrm{g}^{-1}$ & {$[156]$} \\
\hline$"$ & Phenolic compounds & $\mathrm{BSS} / \mathrm{SCS} / \mathrm{PW}$ & $149.25 \mathrm{mg} \mathrm{g}^{-1}$ & [149] \\
\hline$"$ & Phenolic compounds & $\mathrm{BSS} / \mathrm{SCS} / \mathrm{PW}$ & $42.3191 \mathrm{mg} \mathrm{g}^{-1}(298 \mathrm{~K})$ & [147] \\
\hline$"$ & Phenolic compounds & $\mathrm{BSS} / \mathrm{SCS} / \mathrm{PW}$ & $50-80 \mathrm{mg} \mathrm{g}^{-1}$ & {$[148]$} \\
\hline $\begin{array}{l}\text { Commercial } A C(C A C) \\
\text { and agro-waste } \\
\text { based AC (AWAC) }\end{array}$ & Dyes & BSS/SCS/PW & $\begin{array}{l}980.3 \mathrm{mg} \mathrm{g}^{-1}(\mathrm{CAC}) \\
143.2-472.1 \mathrm{mg} \mathrm{g}^{-1}(\text { AWAC })\end{array}$ & {$[142]$} \\
\hline \multicolumn{5}{|l|}{ Clay-based materials } \\
\hline Bentonite & Dyes & BSS/MCS/PW & $430 \mathrm{mg} \mathrm{g}^{-1}$ & [189] \\
\hline$"$ & PAHs & BSS/MCS/PW & $94-95 \%$ & [189] \\
\hline$"$ & Pharmaceuticals & BSS/SCS/PW & $47 \mathrm{mg} \mathrm{g}^{-1}$ & {$[314]$} \\
\hline Organo-bentonite & Dyes & $\mathrm{BSS} / \mathrm{MCS} / \mathrm{PW}$ & $\begin{array}{l}>99 \% \\
868.1 \mathrm{mg} \mathrm{g}^{-1}\end{array}$ & [191] \\
\hline$"$ & Surfactants & $\mathrm{BSS} / \mathrm{MCS} / \mathrm{PW}$ & $\begin{array}{l}>99 \% \\
980.8 \mathrm{mg} \mathrm{g}^{-1}\end{array}$ & {$[191]$} \\
\hline $\begin{array}{l}\text { Several } \\
\quad \text { organo-bentonite }\end{array}$ & PAHs & BSS/SCS/PW & $K_{\mathrm{d}} \max =1.7-36.2 \mathrm{Lg}^{-1}$ & [197] \\
\hline Kaolinite & Pesticides & BSS/MCS/PW & $K_{\mathrm{d}}=0.039-0.052 \mathrm{Lg}^{-1}$ & [193] \\
\hline$"$ & Pesticides & BSS/SCS/PW & $K_{\mathrm{d}}=0.21 \mathrm{Lg}^{-1}$ & {$[192]$} \\
\hline$"$ & Pesticides & $\mathrm{BSS} / \mathrm{SCS} / \mathrm{PW}$ & $K_{\mathrm{d}}=0.009-0.041 \mathrm{Lg}^{-1}$ & {$[194]$} \\
\hline$"$ & Pharmaceuticals & BSS/SCS/PW & $3.1 \mathrm{mg} \mathrm{g}^{-1}$ & {$[157]$} \\
\hline$"$ & Pharmaceuticals & BSS/MCS/PW & Poor fit of the Langmuir model & {$[176]$} \\
\hline$"$ & Phenolic compounds & BSS/SCS/PW & $0.11-2.16 \mathrm{mg} \mathrm{g}^{-1}$ & {$[198]$} \\
\hline Montmorillonite & Aromatic compounds & $\mathrm{BSS} / \mathrm{SCS} / \mathrm{PW}$ & $K_{\mathrm{d}}=1.48-213 \mathrm{Lg}^{-1}$ & {$[174]$} \\
\hline " & Aromatic compounds & $\mathrm{BSS} / \mathrm{MCS} / \mathrm{PW}$ & $K_{\mathrm{d}}=0.03-4 \mathrm{Lg}^{-1}$ & {$[124]$} \\
\hline$"$ & Pesticides & $\mathrm{BSS} / \mathrm{MCS} / \mathrm{PW}$ & $K_{\mathrm{d}}=67-119 \mathrm{Lg}^{-1}$ & [193] \\
\hline$"$ & Pesticides & $\mathrm{BSS} / \mathrm{SCS} / \mathrm{PW}$ & $K_{\mathrm{d}}=0.18 \mathrm{Lg}^{-1}$ & {$[192]$} \\
\hline$"$ & Pesticides & $\mathrm{BSS} / \mathrm{SCS} / \mathrm{PW}$ & $K_{\mathrm{d}}=0.005-0.014 \mathrm{Lg}^{-1}$ & {$[194]$} \\
\hline$"$ & Pharmaceuticals & $\mathrm{BSS} / \mathrm{SCS} / \mathrm{PW}$ & $6.1 \mathrm{mg} \mathrm{g}^{-1}$ & {$[157]$} \\
\hline$"$ & Pharmaceuticals & BSS/MCS/PW & Poor fit of the Langmuir model & {$[176]$} \\
\hline$"$ & Pharmaceuticals & BSS/SCS/PW & $0.88 \mathrm{mmol} \mathrm{g}^{-1}$ & {$[177]$} \\
\hline $\begin{array}{l}\text { Montmorillonite } \\
\text { (cation-saturated } \\
\text { and with surfactants) }\end{array}$ & Pharmaceuticals & $\mathrm{BSS} / \mathrm{SCS} / \mathrm{PW}$ & $\begin{array}{l}K_{\mathrm{d}}=0.048-0.073 \mathrm{Lg}^{-1}\left(\mathrm{~K}^{+} \text {and } \mathrm{Ca}^{2+}\right. \\
\text { saturated), } K_{\mathrm{d}}=0.705 \mathrm{Lg}^{-1} \text { (with } \\
\text { surfactant) }\end{array}$ & {$[175]$} \\
\hline Montmorillonite & Phenolic compounds & $\mathrm{BSS} / \mathrm{SCS} / \mathrm{PW}$ & $0.07-0.62 \mathrm{mg} \mathrm{g}^{-1}$ & {$[198]$} \\
\hline Sepiolite & Dyes & $\mathrm{BSS} / \mathrm{SCS} / \mathrm{PW}$ & $2.82-13.5 \mu \mathrm{mol} \mathrm{g}^{-1}$ & {$[182]$} \\
\hline $\begin{array}{l}\text { Sepiolite (raw and } \\
\text { calcined) }\end{array}$ & Dyes & $\mathrm{BSS} / \mathrm{SCS} / \mathrm{PW}$ & $\begin{array}{l}12.1 \mu \mathrm{mol} \mathrm{g}^{-1} \text { (raw), 9.8-16.2 } \mu \mathrm{mol} \mathrm{g}^{-1} \\
\text { (calcined) }\end{array}$ & {$[185]$} \\
\hline $\begin{array}{l}\text { Sepiolite (raw and } \\
\text { activated) }\end{array}$ & Dyes & BSS/SCS/PW & $\begin{array}{l}0.18 \mathrm{mmol} \mathrm{g}^{-1} \text { (raw), } 0.41 \mathrm{mmol} \mathrm{g}^{-1} \\
\text { (activated) }\end{array}$ & {$[186]$} \\
\hline Sepiolite & Dyes & $\mathrm{BSS} / \mathrm{SCS} / \mathrm{PW}$ & $155.5 \mathrm{mg} \mathrm{g}^{-1}$ & {$[184]$} \\
\hline$"$ & Dyes & $\mathrm{BSS} / \mathrm{SCS} / \mathrm{PW}$ & $70.6-110.2 \mathrm{mg} \mathrm{g}^{-1}$ & [183] \\
\hline Activated sepiolite & Dyes & $\mathrm{BSS} / \mathrm{SCS} / \mathrm{PW}$ & $4.0-6.5 \mathrm{mg} \mathrm{g}^{-1}$ & {$[187]$} \\
\hline Sepiolite & Pharmaceuticals & $\mathrm{BSS} / \mathrm{SCS} / \mathrm{PW}$ & $36-43 \%$ & [75] \\
\hline Smectite (calcined) & Dyes & $\mathrm{CS} / \mathrm{SCS} / \mathrm{PW}$ & $10.36 \mathrm{mg} \mathrm{g}^{-1}$ & [190] \\
\hline $\begin{array}{l}\text { Smectites (saturated } \\
\text { with } \mathrm{K}^{+} \text {and } \mathrm{Ca}^{2+} \text { ) }\end{array}$ & Phenolic compounds & $\mathrm{BSS} / \mathrm{SCS} / \mathrm{PW}$ & $31-62 \%\left(\mathrm{~K}^{+}\right), 12-18 \%\left(\mathrm{Ca}^{2+}\right)$ & [125] \\
\hline Vermiculite & Dyes & $\mathrm{BSS} / \mathrm{SCS} / \mathrm{SWW}$ & $72-106 \mathrm{mg} \mathrm{g}^{-1}$ & {$[188]$} \\
\hline Expanded vermiculite & Pharmaceuticals & BSS/SCS/PW & $51-60 \%$ & [75] \\
\hline Expanded clay & Organic matter & CWS/MCS/WW & $88 \% \mathrm{BOD}_{5} ; 92 \%$ COD & [46] \\
\hline$"$ & Organic matter & $\mathrm{CWS} / \mathrm{MCS} / \mathrm{WW}$ & $59.1 \% \mathrm{BOD}_{5} ; 52.3 \%$ COD & [206] \\
\hline$"$ & Organic matter & $\mathrm{CWS} / \mathrm{MCS} / \mathrm{WW}$ & $91 \% \mathrm{BOD}_{7}$ & [204] \\
\hline
\end{tabular}


Table 2 (Continued)

\begin{tabular}{|c|c|c|c|c|}
\hline Material $^{\mathrm{a}}$ & Pollutants & $\begin{array}{l}\text { Study type (assay } \\
\text { type/mixture } \\
\text { type/solvent) }\end{array}$ & Removal efficiency/sorption capacity & Reference \\
\hline$"$ & Organic matter & $\begin{array}{l}\mathrm{CWS} / \mathrm{MCS} / \mathrm{SWW} \\
\text { and CWS/MCS/WW }\end{array}$ & $65-93 \%$ & {$[84]$} \\
\hline$"$ & Pesticides & $\mathrm{BSS} / \mathrm{SCS} / \mathrm{PW}$ & $0.0099-0.0278 \mathrm{mg} \mathrm{g}^{-1}$ & [74] \\
\hline$"$ & Pharmaceuticals & $\mathrm{BSS} / \mathrm{SCS} / \mathrm{PW}$ & $0.0045-0.0123 \mathrm{mg} \mathrm{g}^{-1}$ & [74] \\
\hline$"$ & Pharmaceuticals & $\begin{array}{l}\mathrm{BSS} / \mathrm{SCS} / \mathrm{PW} \\
\mathrm{BSS} / \mathrm{MCS} / \mathrm{PW} \\
\mathrm{BSS} / \mathrm{MCS} / \mathrm{WW}\end{array}$ & $\begin{array}{l}58-95 \%(\mathrm{SCS} / \mathrm{PW}), 51-93 \%(\mathrm{MCS} / \mathrm{WW}) \\
0.023-0.033 \mathrm{mg} \mathrm{g}^{-1}(\mathrm{SCS} / \mathrm{PW}) \\
0.014-0.030 \mathrm{mg} \mathrm{g}^{-1}(\mathrm{MCS} / \mathrm{PW}) \\
0.011-0.027 \mathrm{mg} \mathrm{g}^{-1}(\mathrm{MCS} / \mathrm{WW})\end{array}$ & [75] \\
\hline$"$ & Pharmaceuticals & CWS/SCS/WW & $\begin{array}{l}82.0 \% \text { (unplanted) } \\
92.5-94.5 \% \text { (planted) }\end{array}$ & [47] \\
\hline$"$ & Pharmaceuticals & CWS/MCS/WW & $\begin{array}{l}\text { 43-91\% (unplanted, summer) } \\
41-87 \% \text { (unplanted, winter) } \\
75-97 \% \text { (planted, summer) } \\
48-88 \% \text { (planted, winter) }\end{array}$ & {$[42]$} \\
\hline Organovermiculite & Pesticides & $\mathrm{BSS} / \mathrm{SCS} / \mathrm{PW}$ & $K_{\mathrm{d}}=0.015-0.355 \mathrm{Lg}^{-1}$ & [195] \\
\hline Organoclays (various) & Pesticides & $\begin{array}{l}\mathrm{BSS} / \mathrm{SCS} / \mathrm{PW} \\
\mathrm{CS} / \mathrm{SCS} / \mathrm{PW}\end{array}$ & $66-100 \%$ & [196] \\
\hline \multicolumn{5}{|c|}{ Zeolites and other siliceous materials } \\
\hline $\begin{array}{l}\text { Natural (clinoptilolite), } \\
\text { ZSM-5, both with } \\
\text { surfactant }\end{array}$ & BTEX & $\begin{array}{l}\text { BSS/SCS/90\%water: } \\
\text { 10\%ethanol }\end{array}$ & $\begin{array}{l}0.171-0.296 \mathrm{mmol} \mathrm{g}^{-1} \text { (cli.), } \\
0.036-0.192 \mathrm{mmol} \mathrm{g}^{-1}(\mathrm{ZSM}-5)\end{array}$ & {$[211]$} \\
\hline $\begin{array}{l}\text { Natural ( } 92 \% \\
\text { clinoptilolite) with } \\
\text { surfactant }\end{array}$ & BTEX & $\mathrm{BSS} / \mathrm{SCS} / \mathrm{PW}$ & $\begin{array}{l}K_{\mathrm{d}}=0.012 \mathrm{Lg}^{-1} \text { (bilayer of } \\
\text { surfactant)-0.013 } \mathrm{Lg}^{-1} \text { (monolayer of } \\
\text { surfactant) }\end{array}$ & [210] \\
\hline $\begin{array}{l}\text { Unspecified type with } \\
\text { surfactant }\end{array}$ & BTEX & $\mathrm{CS} / \mathrm{MCS} / \mathrm{WW}$ & $K_{\mathrm{d}}=0.018-0.095 \mathrm{Lg}^{-1}$ & [236] \\
\hline $\begin{array}{l}\text { Natural ( } 92 \% \\
\text { clinoptilolite) with } \\
\text { surfactant }\end{array}$ & Dyes & BSS/SCS/PW & $61-111 \mathrm{mg} \mathrm{g}^{-1}$ & [213] \\
\hline $\begin{array}{l}\text { Natural }(92 \% \\
\text { clinoptilolite) with } \\
\text { surfactant }\end{array}$ & Dyes & $\mathrm{BSS} / \mathrm{SCS} / \mathrm{PW}$ & $25-35 \%$ & [233] \\
\hline $\begin{array}{l}\text { Natural }(68.5 \% \\
\text { clinoptilolite) }\end{array}$ & Dyes & $\mathrm{BSS} / \mathrm{SCS} / \mathrm{PW}$ & $16.4-19.9 \mathrm{mg} \mathrm{g}^{-1}$ & [215] \\
\hline DAZ-P, DAY-P & Dyes & BSS/SCS/PW & $<15 \%$ & {$[230]$} \\
\hline $\begin{array}{l}\text { Natural }(90 \% \\
\text { clinoptilolite) with } \\
\text { surfactant }\end{array}$ & Dyes & $\mathrm{BSS} / \mathrm{MCS} / \mathrm{PW}$ & $14.9-55.9 \mathrm{mg} \mathrm{g}^{-1}$ & [146] \\
\hline $\begin{array}{l}\text { Natural }(92 \% \\
\text { clinoptilolite) with } \\
\text { surfactant }\end{array}$ & Dyes & BSS/SCS/PW & $61-111 \mathrm{mg} \mathrm{g}^{-1}$ & [214] \\
\hline DAY & PAHs & $\begin{array}{l}\text { BSS/SCS/water- } \\
\text { butanol }\end{array}$ & $769.231 \mathrm{mg} \mathrm{g}^{-1}$ & [231] \\
\hline $\begin{array}{l}\text { Natural }(90 \% \\
\text { clinoptilolite) with } \\
\text { chlorosilanes }\end{array}$ & PAHs & BSS/SCS/PW & $35-54 \%$ & [209] \\
\hline$A, X$ & Pesticides & BSS/SCS/PW & $55 \% \max .(A), 80 \% \max .(X)$ & {$[227]$} \\
\hline $\begin{array}{l}\text { Natural }(80 \% \\
\text { clinoptilolite) with } \\
\text { surfactant }\end{array}$ & Pesticides & $\begin{array}{l}\mathrm{BSS} / \mathrm{SCS} / \mathrm{PW} \text { and } \\
\mathrm{CS} / \mathrm{SCS} / \mathrm{PW}\end{array}$ & $2.0-4.4 \mu \mathrm{mol} \mathrm{g}^{-1}$ & [219] \\
\hline Y & Pharmaceuticals & $\mathrm{BSS} / \mathrm{MCS} / \mathrm{PW}$ & $>90 \%$ (saturated solutions) & [229] \\
\hline $\begin{array}{l}\text { Natural }(80 \% \\
\text { clinoptilolite) with } \\
\text { surfactant }\end{array}$ & Pharmaceuticals & $\mathrm{BSS} / \mathrm{SCS} / \mathrm{PW}$ & $0.07-0.16 \mathrm{mmol} \mathrm{g}^{-1}$ & [220] \\
\hline Y, mordenite, ZSM-5 & Pharmaceuticals & $\begin{array}{l}\mathrm{BSS} / \mathrm{SCS} / \mathrm{PW} \text { and } \\
\mathrm{BSS} / \mathrm{MCS} / \mathrm{WW} \text { (in } \\
\mathrm{Y})\end{array}$ & $\begin{array}{l}42-100 \mathrm{mg} \mathrm{g}^{-1}(\mathrm{Y}-\mathrm{PW}), 26-32 \mathrm{mg} \mathrm{g}^{-1} \\
\text { (mor.-PW), 16-26 mg g }{ }^{-1} \text { (ZSM-5-PW), } \\
96-100 \%(Y-W W)\end{array}$ & {$[222]$} \\
\hline $\begin{array}{l}\text { Natural (clinoptilolite), } \\
\text { Beta, ZSM-5 }\end{array}$ & Pharmaceuticals & $\mathrm{BSS} / \mathrm{SCS} / \mathrm{PW}$ & $\begin{array}{l}1.0 \mathrm{mmol} \mathrm{g}^{-1} \text { (Beta), } 0.07 \mathrm{mmol} \mathrm{g}^{-1} \\
(\mathrm{ZSM}-5), 0.04 \mathrm{mmol} \mathrm{g}^{-1} \text { (cli.) }\end{array}$ & {$[221]$} \\
\hline Beta, ZSM-5 & Phenolic compounds & $\mathrm{BSS} / \mathrm{SCS} / \mathrm{PW}$ & $\begin{array}{l}0.64-0.72 \mathrm{mmol} \mathrm{g}^{-1} \text { (Beta) } \\
0.22-0.55 \mathrm{mmol} \mathrm{g}^{-1} \text { (ZSM-5) }\end{array}$ & [223] \\
\hline $\begin{array}{l}\text { Synthetic Na-Y, } \\
\mathrm{Ni} / \mathrm{Na}-\mathrm{Y}\end{array}$ & Phenolic compounds & $\mathrm{BSS} / \mathrm{SCS} / \mathrm{PW}$ & $\begin{array}{l}0.8-0.9 \mathrm{mmol} \mathrm{g}^{-1}(\mathrm{Na}-\mathrm{Y}) \\
0.9-1.1 \mathrm{mmol} \mathrm{g}^{-1}(\mathrm{Ni} / \mathrm{Na}-\mathrm{Y})\end{array}$ & [228] \\
\hline $\begin{array}{l}\text { Natural (clinoptilolite), } \\
\text { ZSM-5, both with } \\
\text { surfactant }\end{array}$ & Phenolic compounds & $\begin{array}{l}\text { BSS/SCS/90\%water: } \\
\text { 10\%ethanol }\end{array}$ & $\begin{array}{l}0.082-0.126 \mathrm{mmol} \mathrm{g}^{-1} \text { (cli.), } \\
0.020-0.100 \mathrm{mmol} \mathrm{g}^{-1}(\mathrm{ZSM}-5)\end{array}$ & [211] \\
\hline $\begin{array}{l}\text { Y, Beta, mordenite, } \\
\text { ZSM-5 }\end{array}$ & Phenolic compounds & $\begin{array}{l}\mathrm{BSS} / \mathrm{SCS} / \mathrm{PW} \text { and } \\
\mathrm{CS} / \mathrm{SCS} / \mathrm{PW}\end{array}$ & $\begin{array}{l}\text { 85\% (Beta), 70\%(ZSM-5), 65\% (Y), and } \\
50 \% \text { (mor.) } \\
0.723 \mathrm{mmol} \mathrm{g}^{-1} \text { (Beta), } 0.595 \mathrm{mmol} \mathrm{g}^{-1} \\
\text { (ZSM-5), } 0.553 \mathrm{mmol} \mathrm{g}^{-1} \text { (Y), } \\
0.361 \mathrm{mmol} \mathrm{g}^{-1} \text { (mor.) }\end{array}$ & [225] \\
\hline DAY & Phenolic compounds & $\mathrm{CS} / \mathrm{MCS} / \mathrm{PW}$ & $0.8-1.7 \mathrm{mmol} \mathrm{g}^{-1}$ & {$[232]$} \\
\hline
\end{tabular}


Table 2 (Continued)

\begin{tabular}{|c|c|c|c|c|}
\hline Material $^{\mathrm{a}}$ & Pollutants & $\begin{array}{l}\text { Study type (assay } \\
\text { type/mixture } \\
\text { type/solvent) }\end{array}$ & Removal efficiency/sorption capacity & Reference \\
\hline $\begin{array}{l}\text { Natural ( } 97 \% \\
\text { clinoptilolite) with } \\
\text { surfactant }\end{array}$ & Phenolic compounds & BSS/MCS/PW & $\begin{array}{l}41-80 \% ; \\
0.7647-12.7065 \mathrm{mg} \mathrm{g}^{-1}\end{array}$ & {$[212]$} \\
\hline $\begin{array}{l}\text { Natural ( } 92 \% \\
\text { clinoptilolite) with } \\
\text { surfactant }\end{array}$ & Phenolic compounds & $\mathrm{BSS} / \mathrm{SCS} / \mathrm{PW}$ & $K_{\mathrm{d}}=0.011 \mathrm{Lg}^{-1}$ & {$[210]$} \\
\hline $\begin{array}{l}\text { Natural (natrolite and } \\
\text { clinoptilolite) both } \\
\text { with and without } \\
\text { cyclodextrin }\end{array}$ & Phenolic compounds & $\mathrm{BSS} / \mathrm{MCS} / \mathrm{PW}$ & $\begin{array}{l}32-42 \% \text { (natr.), } 47-64 \% \text { (cli.), } 47-54 \% \\
\text { (natr. w/CD), 66-74\% (cli. w/CD) }\end{array}$ & [208] \\
\hline $\begin{array}{l}\text { Natural }(88 \% \\
\text { clinoptilolite) }\end{array}$ & Phenolic compounds & CWS/MCS/WW & $74-90 \%$ & [238] \\
\hline Unspecified type & Organic matter & CWS/MCS/SWW & $97-98.2 \% \mathrm{BOD}_{5}$ & {$[241]$} \\
\hline Clinoptilolite & Organic matter & CWS/MCS/WW & $71.4-73.9 \%$ COD & [240] \\
\hline $\begin{array}{l}\text { Natural (33\% } \\
\text { clinoptilolite) }\end{array}$ & Organic matter & CWS/MCS/WW & $90-93 \%$ BOD $_{5}$ & [239] \\
\hline \multicolumn{5}{|c|}{ Other Aromatic compounds } \\
\hline $\begin{array}{l}\text { Natural (92\% } \\
\text { clinoptilolite) with } \\
\text { and without } \\
\text { surfactant }\end{array}$ & Aniline & $\begin{array}{l}\mathrm{BSS} / \mathrm{SCS} / \mathrm{PW} \text { and } \\
\mathrm{CS} / \mathrm{SCS} / \mathrm{PW}\end{array}$ & $0 \mathrm{mg} \mathrm{g}^{-1}$ (nat.), $2.36 \mathrm{mg} \mathrm{g}^{-1}$ (mod.) & [235] \\
\hline DAY & Aniline derivatives & $\mathrm{CS} / \mathrm{MCS} / \mathrm{PW}$ & $1.2-1.6 \mathrm{mmol} \mathrm{g}^{-1}$ & {$[232]$} \\
\hline $\begin{array}{l}\text { Natural ( } 92 \% \\
\text { clinoptilolite) with } \\
\text { surfactant }\end{array}$ & Aniline & $\mathrm{BSS} / \mathrm{SCS} / \mathrm{PW}$ & $\begin{array}{l}K_{\mathrm{d}}=0.004 \mathrm{Lg}^{-1} \text { (bilayer of } \\
\text { surfactant)-0.005 Lg-1 (monolayer of } \\
\text { surfactant) }\end{array}$ & [210] \\
\hline $\begin{array}{l}\text { Natural (natrolite and } \\
\text { clinoptilolite) both } \\
\text { with and without } \\
\text { cyclodextrin }\end{array}$ & $\begin{array}{l}\text { Aniline and aniline } \\
\text { derivatives }\end{array}$ & $\mathrm{BSS} / \mathrm{MCS} / \mathrm{PW}$ & $\begin{array}{l}34-36 \% \text { (natr.), 45-49\% (cli.), 46-49\% } \\
\text { (natr. w/CD), 65-67\% (cli. w/CD) }\end{array}$ & [208] \\
\hline $\begin{array}{l}\text { NaP1, hydroxysodalite } \\
\text { (HS) with (m) and } \\
\text { without (u) } \\
\text { surfactant }\end{array}$ & Bisphenol A & $\mathrm{BSS} / \mathrm{SCS} / \mathrm{PW}$ & $\begin{array}{l}1.4 \mathrm{mg} \mathrm{g}^{-1}(\mathrm{NaP} 1 \mathrm{u}), 3.5 \mathrm{mg} \mathrm{g}^{-1}(\mathrm{HSu}) \\
56.8 \mathrm{mg} \mathrm{g}^{-1}(\mathrm{NaP} 1 \mathrm{~m}), 114.9 \mathrm{mg} \mathrm{g}^{-1} \\
(\mathrm{HSm})\end{array}$ & [226] \\
\hline $\begin{array}{l}\text { Natural ( } 92 \% \\
\text { clinoptilolite) with } \\
\text { and without } \\
\text { surfactant }\end{array}$ & Nitrobenzene & $\begin{array}{l}\mathrm{BSS} / \mathrm{SCS} / \mathrm{PW} \text { and } \\
\mathrm{CS} / \mathrm{SCS} / \mathrm{PW}\end{array}$ & $2.5 \mathrm{mg} \mathrm{g}^{-1}$ (nat.), $3.25 \mathrm{mg} \mathrm{g}^{-1}$ (mod.) & [235] \\
\hline \multicolumn{5}{|l|}{ Other siliceous materials } \\
\hline Expanded perlite & Pesticides & BSS/SCS/PW & $<5 \%$ & [74] \\
\hline$"$ & Pharmaceuticals & BSS/SCS/PW & $<5 \%$ & {$[74]$} \\
\hline$"$ & Dyes & $\mathrm{BSS} / \mathrm{SCS} / \mathrm{PW}$ & $\begin{array}{l}63-76 \% \\
55.55 \mathrm{mg} \mathrm{g}^{-1}\end{array}$ & {$[246]$} \\
\hline $\begin{array}{l}\text { Perlite and expanded } \\
\text { perlite }\end{array}$ & Dyes & $\mathrm{BSS} / \mathrm{SCS} / \mathrm{PW}$ & $43 \%$ (raw), 65\% (expanded) & [247] \\
\hline $\begin{array}{l}\text { Perlite and expanded } \\
\text { perlite }\end{array}$ & Surfactants & $\mathrm{BSS} / \mathrm{SCS} / \mathrm{PW}$ & $\begin{array}{l}9.8 \mu \mathrm{mol} \mathrm{g}^{-1} \text { (raw) } \\
89.3 \mu \mathrm{mol} \mathrm{g}^{-1} \text { (expanded) }\end{array}$ & [248] \\
\hline$"$ & Dyes & $\mathrm{BSS} / \mathrm{SCS} / \mathrm{PW}$ & $\begin{array}{l}\sim 15-55 \% \\
K_{\mathrm{d}}=0.18-0.42 \mathrm{Lg}^{-1}\end{array}$ & {$[251]$} \\
\hline Diatomite & Dyes & BSS/SCS/PW & $5.92-117.75 \mathrm{mg} \mathrm{g}^{-1} ; 28.6-99.23 \%$ & {$[250]$} \\
\hline$"$ & Dyes & $\mathrm{BSS} / \mathrm{SCS} / \mathrm{PW}$ & $26.04 \mathrm{mg} \mathrm{g}^{-1}$ & {$[254]$} \\
\hline$"$ & Dyes & $\mathrm{BSS} / \mathrm{MCS} / \mathrm{PW}$ & $47 \mathrm{mg} \mathrm{g}^{-1}$ & {$[252]$} \\
\hline$"$ & Dyes & BSS/SCS/PW & $94.46-137.0 \mathrm{mg} \mathrm{g}^{-1}$ & {$[253]$} \\
\hline$"$ & Other aromatics & $\mathrm{BSS} / \mathrm{SCS} / \mathrm{PW}$ & $0.73 \mathrm{mg} \mathrm{g}^{-1}$ & {$[257]$} \\
\hline$"$ & Pesticides & $\mathrm{BSS} / \mathrm{SCS} / \mathrm{NW}$ & $55-95 \%$ & {$[255]$} \\
\hline$"$ & Phenolic compounds & BSS/SCS/PW & $92 \mathrm{mg} \mathrm{g}^{-1}$ & {$[256]$} \\
\hline \multicolumn{5}{|c|}{ Industrial wastes and by-products } \\
\hline Fly ash & Dyes & $\mathrm{BSS} / \mathrm{SCS} / \mathrm{PW}$ & $3-240 \mu \mathrm{mol} \mathrm{g}^{-1}$ & {$[262]$} \\
\hline$"$ & Dyes & BSS/SCS/PW & $13.5-97.6 \mu \mathrm{mol} \mathrm{g}^{-1}$ & [263] \\
\hline$"$ & Dyes & $\mathrm{BSS} / \mathrm{SCS} / \mathrm{SW}$ & $20 \mu \mathrm{molg}^{-1}$ & {$[260]$} \\
\hline$"$ & Organic matter & CWS/MCS/WW & $47 \%$ & {$[274]$} \\
\hline$"$ & PAHs & $\begin{array}{l}\text { BSS/MCS/Several } \\
\text { solvents }\end{array}$ & $25-100 \%$ & [266] \\
\hline$"$ & PCBs & $\begin{array}{l}\text { BSS/MCS/Several } \\
\text { solvents }\end{array}$ & $0-30 \%$ & [266] \\
\hline$"$ & PCBs & BSS/SCS/PW & $<97 \%$ & [267] \\
\hline$"$ & Pesticides & $\mathrm{BSS} / \mathrm{SCS} / \mathrm{PW}$ & $0.56-3.33 \mathrm{mg} \mathrm{g}^{-1}$ & [264] \\
\hline$"$ & $\begin{array}{l}\text { Petroleum hydrocarbons } \\
\text { (PAH and BTEX) }\end{array}$ & BSS/SCS/PW & $0.10-108.4 \mathrm{Lkg}^{-1}$ & [265] \\
\hline$"$ & Phenolic compounds & BSS/MCS/PW & $88.9-92.6 \%$ & {$[258]$} \\
\hline$"$ & Phenolic compounds & BSS/SCS/PW & $6.24-15.67 \mathrm{mg} \mathrm{g}^{-1}(303 \mathrm{~K})$ & [259] \\
\hline Bagasse fly ash & Phenolic compounds & $\mathrm{BSS} / \mathrm{SCS} / \mathrm{PW}$ & $23.83 \mathrm{mg} \mathrm{g}^{-1}$ & [269] \\
\hline$"$ & Pesticides & $\begin{array}{l}\mathrm{BSS} / \mathrm{SCS} / / \mathrm{PW} \text { and } \\
\mathrm{BSS} / \mathrm{SCS} / \mathrm{NW}\end{array}$ & $0.39 \mathrm{mmol} \mathrm{g}^{-1}(\mathrm{PW}) ; 94-99 \%(\mathrm{NW})$ & [271] \\
\hline
\end{tabular}


Table 2 (Continued)

\begin{tabular}{|c|c|c|c|c|}
\hline Material $^{\mathrm{a}}$ & Pollutants & $\begin{array}{l}\text { Study type (assay } \\
\text { type/mixture } \\
\text { type/solvent) }\end{array}$ & Removal efficiency/sorption capacity & Reference \\
\hline Blast furnace dust & Pesticides & BSS/MCS/PW & $13-21 \mathrm{mg} \mathrm{g}^{-1}$ & [315] \\
\hline Blast furnace dust & Phenolic compounds & BSS/MCS/PW & $9.5-13.8 \mathrm{mg} \mathrm{g}^{-1}$ & [316] \\
\hline Blast furnace slag & Dyes & $\mathrm{BSS} / \mathrm{SCS} / \mathrm{PW}$ & $1.15 \mathrm{mg} \mathrm{g}^{-1}$ & [317] \\
\hline Blast furnace sludge & Dyes & $\mathrm{BSS} / \mathrm{SCS} / \mathrm{PW}$ & $1.3-2.1 \mathrm{mg} \mathrm{g}^{-1}$ & [318] \\
\hline " & Pesticides & $\mathrm{BSS} / \mathrm{MCS} / \mathrm{PW}$ & $23-30 \mathrm{mg} \mathrm{g}^{-1}$ & [315] \\
\hline$"$ & Phenolic compounds & BSS/MCS/PW & $12.7-18.9 \mathrm{mg} \mathrm{g}^{-1}$ & [316] \\
\hline Red mud & Phenolic compounds & BSS/SCS/PW & $4.127 \mathrm{mg} \mathrm{g}^{-1}$ & [319] \\
\hline Rice husk ash & Phenolic compounds & BSS/SCS//PW & $1.63-153 \mu \mathrm{mol} \mathrm{g}^{-1}$ & [273] \\
\hline \multicolumn{5}{|c|}{ Agricultural wastes and by products } \\
\hline Almond shell & Dyes & $\mathrm{BSS} / \mathrm{SCS} / \mathrm{PW}$ & $\begin{array}{l}97 \% \\
20.5 \mathrm{mg} \mathrm{g}^{-1} \text { (almond shell mixture) }\end{array}$ & [301] \\
\hline Almond shell & Dyes & $\mathrm{BSS} / \mathrm{SCS} / \mathrm{PW}$ & $51.02-76.34 \mathrm{mg} \mathrm{g}^{-1}$ & [296] \\
\hline$"$ & Dyes & $\mathrm{BSS} / \mathrm{SCS} / \mathrm{PW}$ & $29.0 \mathrm{mg} \mathrm{g}^{-1}$ & [298] \\
\hline$"$ & Dyes & $\mathrm{BSS} / \mathrm{SCS} / \mathrm{PW}$ & $32.6 \mathrm{mg} \mathrm{g}^{-1}$ & [297] \\
\hline$"$ & Hormones & BSS/SCS/PW & $90 \%$ & [305] \\
\hline$"$ & Pharmaceuticals & $\mathrm{BSS} / \mathrm{SCS} / \mathrm{PW}$ & $2.5 \mathrm{mg} \mathrm{g}^{-1}$ & [307] \\
\hline$"$ & Phenolic compounds & $\mathrm{BSS} / \mathrm{SCS} / \mathrm{PW}$ & $93 \%$ & [290] \\
\hline$"$ & Phenolic compounds & $\mathrm{CS} / \mathrm{SCS} / \mathrm{PW}$ & $>99.98 \%$ & [291] \\
\hline$"$ & Phenolic compounds & $\begin{array}{l}\mathrm{BSS} / \mathrm{SCS} / \mathrm{PW} \text { and } \\
\mathrm{BSS} / \mathrm{SCS} / \mathrm{WW}\end{array}$ & 91.36\% (PW); 85.54\% (WW) & [292] \\
\hline Banana peel & Pesticides & $\mathrm{BSS} / \mathrm{SCS} / \mathrm{PW}$ & $\begin{array}{l}90-99 \% \\
14 \mathrm{mgg}^{-1}\end{array}$ & [284] \\
\hline$"$ & Phenolic compounds & $\mathrm{BSS} / \mathrm{MCS} / \mathrm{WW}$ & $689 \mathrm{mg} \mathrm{g}^{-1}$ & [293] \\
\hline Chickpea husk & Pesticides & $\begin{array}{l}\mathrm{BSS} / \mathrm{SCS} / \mathrm{PW} \text { and } \\
\mathrm{CS} / \mathrm{SCS} / \mathrm{PW}\end{array}$ & $7.7-25 \mu \mathrm{mol} \mathrm{g}^{-1}$ (BSS) & [288] \\
\hline Coconut fiber & Pesticides & BSS/SCS/PW & $85.9-86.3 \%$ & [285] \\
\hline Coconut shells charcoal & Pesticides & BSS/SCS/PW & $92.4-95.2 \%$ & [285] \\
\hline Coconut shells & Phenolic compounds & $\mathrm{BSS} / \mathrm{SCS} / \mathrm{PW}$ & $205.8 \mathrm{mg} \mathrm{g}^{-1}$ & [294] \\
\hline Cork (granulated) & PAHs & BSS/MCS/PW & $>96 \% ; 0.016-0.049 \mathrm{mg} \mathrm{g}^{-1}$ & [303] \\
\hline Cork & Pesticides & $\mathrm{BSS} / \mathrm{SCS} / \mathrm{PW}$ & $19.08 \mathrm{mg} \mathrm{g}^{-1}$ & [153] \\
\hline Cork (granulated) & Pesticides & $\mathrm{BSS} / \mathrm{SCS} / \mathrm{PW}$ & $80 \% ; 0.26-0.55 \mathrm{mg} \mathrm{g}^{-1}$ & [289] \\
\hline Cork (granulated) & Pesticides & $\mathrm{BSS} / \mathrm{SCS} / \mathrm{PW}$ & $0.136-0.303 \mathrm{mg} \mathrm{g}^{-1}$ & {$[154]$} \\
\hline$"$ & Pharmaceuticals & $\begin{array}{l}\mathrm{BSS} / \mathrm{SCS} \text { and } \\
\mathrm{MCS} / \mathrm{PW} \text { and } \mathrm{WW}\end{array}$ & $\begin{array}{l}0.06056-0.3668 \mathrm{mg} \mathrm{g}^{-1}(\mathrm{SCS}, \mathrm{PW}) \\
8-63 \%(\mathrm{MCS}, \mathrm{WW})\end{array}$ & {$[85]$} \\
\hline Cork bark & Pharmaceuticals & $\mathrm{BSS} / \mathrm{SCS} / \mathrm{PW}$ & $0.99 \mathrm{mg} \mathrm{g}^{-1}$ & {$[306]$} \\
\hline Cork & Phenolic compounds & $\begin{array}{l}\text { BSS/SCS/hydro- } \\
\text { alcoholic } \\
\text { solutions }\end{array}$ & $9.8-31.2 \mathrm{~L} \mathrm{~kg}^{-1}$ & [295] \\
\hline Hazelnut shell & Dyes & BSS/SCS/PW & $0.214 \mathrm{mmol} \mathrm{g}^{-1}$ & [299] \\
\hline$"$ & Dyes & $\begin{array}{l}\mathrm{BSS} / \mathrm{SCS} / \mathrm{PW} \text { and } \\
\mathrm{CS} / \mathrm{SCS} / \mathrm{PW}\end{array}$ & $40.8-76.9 \mathrm{mg} \mathrm{g}^{-1}$ & [300] \\
\hline Pine bark & Hormones & $\mathrm{BSS} / \mathrm{SCS} / / \mathrm{PW}$ & $>99 \%$ & [305] \\
\hline$"$ & Explosives & BSS/SCS/WW & $\begin{array}{l}50-80 \% \\
1.68 \mathrm{mg} \mathrm{g}^{-1}\end{array}$ & {$[304]$} \\
\hline $\begin{array}{l}\text { Pine bark with }(\mathrm{M}) \text { and } \\
\text { without }(\mathrm{U}) \\
\text { modification }\end{array}$ & PAHs & $\mathrm{BSS} / \mathrm{SCS} / \mathrm{PW}$ & $\begin{array}{l}62.9-80.95 \% ; 2.21-3.73 \mathrm{mg} \mathrm{g}^{-1}(\mathrm{U}) \\
39.2-95.48 \% ; 0.68-22.69 \mathrm{mg} \mathrm{g}^{-1}(\mathrm{M})\end{array}$ & [302] \\
\hline Pine bark & Pesticides & $\mathrm{BSS} / \mathrm{SCS} / \mathrm{PW}$ & $10 \mathrm{mg} \mathrm{g}^{-1}$ & [283] \\
\hline$"$ & Pesticides & $\mathrm{CS} / \mathrm{MCS} / \mathrm{WW}$ & $72 \%$ & [282] \\
\hline Rice bran & Pesticides & $\begin{array}{l}\mathrm{BSS} / \mathrm{SCS} / / \mathrm{PW} \text { and } \\
\mathrm{NW}\end{array}$ & $390 \mu \mathrm{molg}^{-1}$ (PW); 94-99\% (NW) & {$[271]$} \\
\hline Rice bran & Pesticides & $\begin{array}{l}\mathrm{BSS} / \mathrm{SCS} / / \mathrm{PW} \text { and } \\
\mathrm{NW}\end{array}$ & $82 \mu \mathrm{molg}^{-1}$ (PW); 98-99\% (NW) & [287] \\
\hline Rice husk & Pesticides & $\begin{array}{l}\text { BSS/SCS//PW and } \\
\text { NW }\end{array}$ & $350 \mu \mathrm{molg}^{-1}(\mathrm{PW}) ; 97 \%(\mathrm{NW})$ & {$[271]$} \\
\hline$"$ & Pesticides & $\begin{array}{l}\mathrm{BSS} / \mathrm{SCS} / / \mathrm{PW} \text { and } \\
\mathrm{NW}\end{array}$ & $25 \mu \mathrm{molg}^{-1}(\mathrm{PW}) ; 94-96 \%(\mathrm{NW})$ & [287] \\
\hline$"$ & Phenolic compounds & CWS/MCS/WW & $100 \%$ (planted), $25-100 \%$ (unplanted) & [311] \\
\hline$"$ & Dyes & $\mathrm{BSS} / \mathrm{SCS} / \mathrm{PW}$ & $\begin{array}{l}\sim 70 \% \\
59 \mu \mathrm{mol} \mathrm{g}^{-1}(313 \mathrm{~K})\end{array}$ & {$[144]$} \\
\hline Wood sawdust & Dyes & $\mathrm{BSS} / \mathrm{SCS} / \mathrm{PW}$ & $26.2-59.2 \mathrm{mg} \mathrm{g}^{-1}$ & {$[300]$} \\
\hline$"$ & Pesticides & $\mathrm{BSS} / \mathrm{SCS} / \mathrm{PW}$ & $69.44 \mathrm{mg} \mathrm{g}^{-1}$ & [153] \\
\hline$"$ & Pesticides & $\mathrm{BSS} / \mathrm{SCS} / \mathrm{PW}$ & $78.5-80.5 \%$ & [285] \\
\hline Wood & Pesticides & $\mathrm{BSS} / \mathrm{SCS} / \mathrm{PW}$ & $40-80 \%$ (untreated wood) & [286] \\
\hline Wood charcoal & Organic matter & CWS/MCS/WW & $95.5 \%$ & [312] \\
\hline
\end{tabular}

a ZSM-5, DAZ-P, DAY, A, X; Y and NaP1 are common abbreviations/designations for certain types of zeolites, as is detailed in the text

b BSS-Batch sorption studies; CS-column studies; CWS-constructed wetlands systems; SCS-single-component solutions; MCS-multi-component solutions; PW-pure water; WW-wastewater; SWW-synthetic wastewater; NW-natural water; CD-cyclodextrin.

Activated carbon has been proven to be an effective adsorbent for the removal of a wide variety of organic pollutants from aqueous media or gaseous environments. A small illustrative sample of the tests that have been conducted to study the adsorption of organic pollutants by activated carbon is presented in Table 2. Among the most commonly tested organic substances, several examples can be found including dyes [141-146], phenolic compounds [147-149], pesticides [150-154], 
pharmaceuticals [155-158] and many other organic pollutants [159-161].

There are two most common physical forms in which activated carbons are used, namely as powdered or granular media. There are other forms that have recently been attracting increasing attention, among them fibers mainly obtained from isotropic coal and petroleum pitch, cloths and felts [162].

Almost any carbonaceous material may be used as a precursor for the preparation of activated carbons, the main requirement being that it possesses a high carbon content. In addition, the selection of the raw materials is based mainly on the following criteria [162]:

\section{- low inorganic matter content,}

- ease of activation (e.g., calcined coke is a "difficult material" while wood char is readily activated),

- availability and low cost,

- low degradation during storage.

However, in practice, commercially available activated carbons are usually derived from natural materials such as wood, nutshells and fruit stones, banana stalks, sawdust, cork, rice husk, coconut shell, straw, peat, bamboo dust, charcoal, soft coal, lignite, bituminous coal, petroleum coke, etc. [140-142,147-150,155,156].

The use of activated carbon (in granular form, due to hydraulic conductivity requirements) as a support matrix for CWS does not meet the same popularity as its use as filter medium, since its effectiveness is not as high to justify its high cost [163-165]. In addition, since it is a less specific adsorbent, its capacity is easily saturated by the complex liquid matrix of wastewaters and its regeneration is difficult when used as CWS bed. In fact, the biggest barrier to the general use of activated carbon is its cost and the difficulties associated with regeneration $[137,140]$. Activated carbon is quite expensive and the higher the quality the greater the cost. The use of carbons based on relatively expensive starting materials is unjustified for most pollution control applications [166]. Also, both chemical and thermal regeneration of spent carbon is expensive, impractical on a large scale and produces additional effluent and results in considerable loss of the adsorbent.

All these shortcomings have led many researchers to look for more economic adsorbents, especially for water pollution control where cost factors play a major role.

\subsubsection{Clay-based materials}

Clay minerals are one of the most common constituents of soils. Its ubiquity in nature makes this class of materials unsurprisingly one of the most extensively studied groups of adsorbents and also a natural choice for at least one of the support matrix components of CWS.

Clays are broadly defined as those minerals that make up the colloid fraction $(<2 \mu \mathrm{m})$ of soils and which may be composed of mixtures of fine-grained clay minerals as well as clay-sized crystals of other minerals (e.g. quartz, carbonates and metal oxides). In a more strict definition, clay minerals are hydrous aluminium phyllosilicates which possess a layered structure. According to the differences in that structure they can be classified as smectites (montmorillonite, saponite), mica (illite), kaolinite, serpentine, pylophyllite (talc), vermiculite and sepiolite [167]. The structure of these minerals features a net negative charge which is balanced by exchangeable cations. These ions can be easily exchanged with some cations from the liquid media $[168,169]$.

The amphiprotic character of silanol and aluminol groups in clays surfaces is responsible for a pH-dependent surface charge in clays (however, water molecules associated with exchangeable cations and clay surfaces may obscure these charged adsorption sites; such effect is dependent on the hydration strength of the exchangeable ions [170-175]). Electrostatic interactions with the surface and mechanisms such as cation exchange, cation bridging with the surface, surface complexation, and hydrogen bonding seem to be involved in the capture of ionic and polar species from aqueous media [121-125,176]. In addition, the interlayer expandability of many of these minerals and the presence of water molecules associated with exchangeable cations in these interlayers allows the exchange of these hydrated ions with much larger organic molecules and their intercalation between the aluminosilicate layers [123,177,178].

Because of this high potential for ion exchange and surface interactions, in addition to the extensive sorption capacities resulting from their large surface areas (due to the sheet structure of these minerals) clays act as natural scavengers of pollutants. For such reasons, and adding to their wide availability and associated low cost, in recent years there has been an increasing interest in utilizing natural clays for the removal of organic contaminants from aqueous solutions (Table 2). However, due to the hydrophilic characteristics of their surfaces and charges, naturally occurring clays seem less effective for the adsorption of anionic contaminants and hydrophobic or non-polar organic pollutants [179].

To increase the ability of mineral clays to remove non-polar and anionic water pollutants, like many other natural materials, clays can also be modified to improve their sorption properties. This modification commonly consists of a simple ion exchange of the natural inorganic interlayer cations with certain organic cations such as quaternary ammonium cations of long hydrocarbon chains. By introducing cationic surfactant molecules into the interlamellar space through ion exchange, the properties of clay minerals are enhanced to those of organoclays [179-181]. The intercalation of a cationic surfactant between the clay layers changes the surface properties from highly hydrophilic to increasingly hydrophobic. At sufficient loading the surfactant forms a bilayer that results in a reversal of the charge on the external surface of the clay adequate for retention of anions, while neutral species can partition into the hydrophobic core. In addition, modification of a swelling clay with a cationic surfactant results in an increase of the basal spacing of the layer and exposure of new adsorption sites. These organoclays have been extensively investigated in recent years for a wide variety of environmental applications.

As an alternative to the chemical modification of clay surfaces, some studies have employed lightweight clay materials that are based on processed natural clays. The typical form of processing consists of some thermal treatment that has the effect of causing interlayer hydration water to quickly vaporize (sometimes complemented with an additional effect of the thermal expansion of injected gases such as $\mathrm{CO}_{2}$ ) with a consequent expansion of the sheet structure of the minerals and formation of pores and channels as the gases escape the softened heated materials. This process yields highly porous materials, with an increased accessible surface area, which can substantially improve the sorbent capacity. Some of the most common processed clay materials that have been used are light expanded clay aggregates (LECA), expanded shale, expanded slate and exfoliated vermiculite.

In terms of hydraulic conductivity requirements, particle sizes of these materials can, in general, be obtained in adequate distributions which allow some control of the hydraulic properties of the medium.

Some of the most popular types of clay minerals (kaolinite, illite, montmorillonite, vermiculite, sepiolite, bentonite) have been tested to remove by adsorption a variety of organic pollutants such as dyes [182-191], pesticides [74,192-196], PAHs [124,189,197], pharmaceuticals [74,75,157,175-177], phenolic compounds [125,174,198] and other aromatics [124,174,189,198]. In the vast majority of these studies the organic substances are 
removed most commonly from pure water solutions in batch adsorption assays.

Clays have been a popular type of materials used as the support matrix of CWS, for reasons not exclusively related with their qualities as sorbents and low cost, but just because they are a typical component of soils and, therefore, in many cases they are naturally present in the support matrix of CWS when soil is used as substrate. Recently, despite the slightly increased cost of production, processed clay materials have also become popular choices for CWS substrates and in any case clay-based materials proved to be an adequate medium for a good performance of CWS $[42,46,47,83,84,126,165,199-206]$.

\subsubsection{Zeolites and other siliceous materials}

The use of zeolites and other natural siliceous sorbents such as perlite, diatomite, silica and glass fibers for organic xenobiotics removal from wastewater is increasing because of their abundance, availability and low cost.

Zeolites are highly porous aluminosilicates featuring a distinctive channel or cage-like structure. They can either occur as natural minerals or can be artificially synthesized. More than 40 natural zeolites are identified in the world, and are available in large deposits in many countries such as Greece, UK, Italy, Mexico, Iran, and Jordan [137]. The most abundant and frequently studied one is clinoptilolite, while only six other types of natural zeolites also exist in sufficient quantity and purity to be considered exploitable, namely mordenite, chabazite, erionite, ferrierite, phillipsite, and analcime [207].

Like in clays, the aluminosilicate framework of zeolites also has a negative lattice charge which is balanced by cations that can be exchangeable with certain cations in solution. The high ion exchange capacity of zeolites, their extensive porosities and specific surface areas, as well as their relatively cheap prices, make natural zeolites attractive adsorbents [208-222]. However, synthetic zeolites are also widely tested, especially because through synthesis a useful control can be obtained over the Si/Al ratio in the zeolite composition. A zeolite with a higher content of the more hydrophobic silicon can show higher affinity for nonpolar organics $[223,224]$. Some of the synthetic zeolites for which studies can be found in the literature are the beta (BEA) zeolite [221,223,225], ZSM-5 [211,221-223], hydroxysodalite [226], zeolite A (LTA) [224,227], zeolite P [226], zeolite X [224,227], zeolite Y $[222,224,228,229]$ and dealuminated Y (DAY) zeolite [230-232].

In fact, many unmodified natural zeolites are not very good adsorbents of anionic compounds [207] and, due to its surface hydrophilics, they are poor adsorbents of most organics as well $[214,226,233]$. However, surface modification can change the surface functionality by adding cationic surfactants or other hydrophobic groups thus making them applicable for adsorption of various anions and organics. The most common surface modifiers are salts of a variety of quaternary amines such as hexadecyltrimethylammonium (HDTMA, the most popular surfactant) [210-214,224,226,234-236], octadecyldimethylbenzylammonium (ODMBA) [216-218], stearyldimethylbenzylammonium (SDBA) [219,224] or benzyltetradecyl ammonium (BDTDA) [212]. Other posibilities are cetylpyridinium salts $[211,220]$, cyclodextrins [208] and chlorosilanes [209].

Zeolites have been intensively studied (a brief sample of these studies is presented in Table 2 ) and considered as viable options (in spite of usually requiring low-cost modifications) to treat wastewater contaminated with trace quantities of organic pollutants [237]. Among some of the organic compounds that have been observed to be successfully removed by zeolites are phenolic compounds [208,210-212,223,225,228,232,238], PAHs [209,231], BTEX [209-211,236], other aromatics such as nitrobenzene, bisphenol A, aniline and aniline derivatives [208,210,226,232,235], dyes
[146,213-215,230,233], pesticides [219,227] and pharmaceuticals [220-222,229].

Efficiency of pollutants removal by modified zeolites has been observed, in most cases, as being proportional to the surfactant content and its coverage of the zeolite surface $[210,216,226]$, which shows that the surfactant is a key component in zeolite adsorption processes. Adsorption by zeolites appears to be also $\mathrm{pH}$ dependent in many cases $[210,216,226,232]$. The state of ionization of the adsorbate is naturally determinant for the extent of ion exchange with zeolite cations (in which case a cationic state is favored) or adsorption/partition to the surfactant (a neutral form is usually more efficiently removed from the liquid in such cases).

There have been already some studies carried out in CWS where zeolites have been used at least as one of the constituents of the support matrix [117,238-242]. Most of the studies focus on the removal of nitrogen, phosphorus and unspecified organics (organic matter) by such CWS, but there have been already some attempts to evaluate the removal of specific organics such as phenolic compounds [238]. These assays together with the studies on adsorption of organics as presented in Table 2 point to the use of zeolites as a viable option for the support matrix of CWS for organic pollutant treatment.

Among other natural siliceous materials, perlite and diatomite are probably the most commonly tested. Perlite is an inexpensive and easily available material that consists of a glassy volcanic rock with a high content of silica (typically $>70 \%$ ) and a relatively high amount of water. As one of its salient characteristics, perlite expands when heated to a suitable temperature. At temperatures between 760 and $1090^{\circ} \mathrm{C}$, which is the softening range of perlite (since it is a glass), the water contained in the crude perlite rock quickly vaporizes and escapes the structure of the material [243], thus causing perlite to significantly expand (10-15 times its original volume) and form a lightweight glasslike solid with a cellular structure and very large surface area.

Almost all perlite is consumed in an expanded form, although a small amount of unexpanded perlite has been used in a few applications. Expanded perlite is mostly used as an excellent filter aid and as a filler in various processes and materials due to its chemical inertness in most environments. In addition, it finds some applications in agriculture for growing of seeds and regularizing of the soil, thus suggesting some potential for use as CWS support matrix. As a sorbent, due to the presence of a significant amount of silanol groups on its surface, it features interesting adsorptive qualities and it has already been studied for the sorption of several different types of organic compounds, namely dyes [244-247], pesticides [74], pharmaceuticals [74] and surfactants [248].

Diatomite, or diatomaceous earth, is a naturally occurring sedimentary rock consisting mainly of the fossilized skeletal remains of diatoms, a type of hard-shelled algae. Its chemical composition is essentially amorphous silica (typically over $80 \%$ of dried diatomite), although variable small amounts of other materials (metal oxides, clays, salts (mainly carbonates) and organic matter) may also be present. Diatomite is a very lightweight material that is easily available and inexpensive. Due to its wide pore size distribution, high permeability, high porosity, small particle size, large surface area and chemical inertness it is considered a good adsorbent with a high adsorption capacity [249-252]. In addition, diatomite has surface charges due to the presence of ionisable functional groups, especially silanol groups, that spread over the matrix of the silica, which are suitable adsorption sites for polar organic compounds.

Diatomite has been tested as an adsorbent for several types of organics, namely dyes [250-254], pesticides [255], phenolic compounds [256] and other aromatics [257]. 


\subsubsection{Industrial and agricultural wastes and by-products}

Huge amounts of solid waste materials are generated by industrial activities, whose disposal, if no proper utilization is found, is the source of a major environmental problem. These wastes (such as sludge, furnace slag, fly ash and red mud) are available almost free of cost (as they are frequently the by-products of some industrial processes) and could be reused as low-cost adsorbents in filter beds or as the support matrix for CWS. Such utilization would provide a two-fold advantage: the volume of waste materials could thus be partly reduced and the materials could be used to reduce pollution at a reasonable cost. In this regard a number of industrial wastes have been studied as adsorbents, more commonly in batch adsorption experiments, for the removal of pollutants (including organic xenobiotics) from wastewaters. Some of the most often tested are presented in Table 2.

Fly ash is a waste material originated in great amounts in combustion processes, especially by thermal power plants. Due to its enrichment in potentially toxic trace elements, namely heavy metals, which condense from the flue gas, it is recognized as a hazardous material, therefore presenting a serious environmental problem concerning the disposal of the large amounts generated by the industry. Some research has been focusing on the study of its sorbent properties and has explored the application of fly ash for treating wastewater (Table 2). Many adsorption studies point to the suitability of fly ash use for retention of hazardous organic pollutants commonly found in many industrial wastewaters such as phenolic compounds [258,259], dyes [260-263], pesticides [264], petroleum hydrocarbons [265], PAHs [266] and PCBs [266,267].

The polarities and water solubilities of the pollutants, fly ash particle sizes and its unburned carbon content, as well as $\mathrm{pH}$ of the media are specified as the main factors with significant effect on the adsorption processes [184,258-260,263-265,267-269]. Depending on the balance between the composition on metal oxides or the residual carbon content, adsorption of polar or mostly non-polar molecules, respectively, may be favored. The $\mathrm{pH}$ of the medium controls the degree of ionization of the compound as well as the surface charge of fly ash particles (by its relation to the point of zero charge) thereby having a usually significant influence on surface electrostatic interactions and on the adsorption process [259,268].

Fly ash seems to be especially efficient for compounds containing aromatic rings, such as phenolic compounds, in comparison to any effects due to other functional groups such as alcohols, aldehydes and ketones [270]. The low polarity and subsequent insolubility of most aromatics partially explains their easy removability by fly ash.

An inconvenience involving the utilization of fly ash in wastewater treatment is the possibility for leaching of some of the significant amounts of elements (metals in particular) that are usually present in this waste material. These potentially hazardous constituents are deposited on fly ash particles during the cooling after combustion and many are readily leachable, thus possibly creating a problem of secondary pollution. The problem is more severe for fly ash originated from combustion of coal, whereas other types resulting from the combustion of materials with a greater amount of organic materials and lower content in inorganic components (such as the bagasse fly ash produced by the sugar industry [269,271] or the rice husk ash $[272,273]$ ) have been considered as safer alternatives.

In contrast to fly ash, research of adsorption properties of other industrial wastes with high contents of inorganic substances, especially metal oxides, and very low carbon contents, have revealed a poor suitability for adsorption of most organic substances (Table 2). Therefore, if these materials have adequate hydraulic characteristics and a low toxicity towards the CWS biota (which is often not the case), and if the risk of becoming themselves a source of pollutants is assessed as low, then they may be used as support matrix but they cannot provide more than the function of an inert filter material for the beds. They may alternatively be submitted to chemical modifications to enhance their sorption qualities or be used as components in a composite support matrix with other materials.

Some industrial waste materials, including fly ash, have already been tested as support matrix components of CWS [242,274-280], although the target of the treatment systems have been mostly nutrients and other inorganic pollutants such as metals. Still, some of these support materials seemed adequate for the development of the biotic CWS components.

Pursuing the idea of reusing some waste materials for wastewater decontamination, in addition to industry by-products various agricultural wastes such as leaves, fibers, fruits peels, seeds, sawdust, bark, etc., have been explored in the last decade as low-cost adsorbents for organic xenobiotics [281]. Some of the most commonly tested and used are presented in Table 2 . The abundance and widespread availability of agricultural by-products make them cheap and readily available sources of raw materials and biosorbents providing a viable economic and eco-friendly option for water and wastewater treatment. In fact, their abundance, renewable nature, low cost and unique chemical composition make them an attractive alternative to other materials commonly used as adsorbents. In most cases, agricultural wastes have been tried in their natural form or with a minimum of processing (washing, drying, grinding) which contributes to the economy of their use as production costs are reduced by avoiding expenses with additional chemicals, energy costs and complications of the modification processes. In addition, agricultural wastes are a rich and interesting source for activated carbon production due to its low ash content.

Most agricultural wastes with high sorption capacity for organic pollutants are lignocellulosic materials. These consist of three main structural components: lignin, cellulose and hemicelluloses. Other basic components include lipids, proteins, simple sugars, water, hydrocarbons, and starch, containing a variety of functional groups. Depending on the composition of the materials, some of them may release substantial amounts of organic matter or specific contaminants over a period of time, a potential problem that has to be carefully assessed when evaluating the use of these wastes in CWS beds.

Recent literature reports several studies on the effective adsorption of many organic compounds such as pesticides [153,154,271,282-289], phenolic compounds [290-295], dyes [144,296-301], PAHs [302,303], explosives [304] and pharmaceuticals and hormonal compounds [85,305-307] by a variety of adsorbents prepared from agricultural wastes. The list of materials that have been tested in such studies is long (and still increasing). Some examples include pine bark [282,283,302,304,305], almond shells [292,307], banana peels [284,293], sawdust [153,285,300], coconut fibers [285], rice bran [271,287], rice husk [271,287], moringa pods [271], hazelnut shells [299,300], wood residues [286], cork wastes [85,153,154,289,295,303,306] and chickpea husk [288]. In addition, assays have also been conducted with some of these materials after submitting them to more or less complex treatments (usually thermal), e.g. chemically modified pine bark [302], almond shell ashes [307], almond shell charcoal [292], walnut shell charcoal [292], wood charcoal [285], coconut shell activated carbon [294], coconut charcoal [285], bagasse charcoal [285], bagasse fly ash [269,271] and chemically treated wood residues [286].

In comparison with other industrial wastes, the generally higher carbon content of agro-wastes is responsible for an improved sorptive performance and a wider range of sorbates for which these sorbents show affinity. In addition they also provide suitable growth media for microorganisms, which has been reported to be useful for the biodegradation of some pollutants [308,309]. 
In addition to sorption studies, some agricultural waste materials have already been tested and proved efficient as support matrix components of CWS [310-313].

Due to the nature and own characteristics of each type of waste material, the particle sizes of some of these materials span very narrow distributions, in which case their hydraulic conductivities cannot be suited for the characteristics of the wastewater, unless they are used mixed with other materials in a composite support matrix.

\subsubsection{General final remarks}

From the sample of published works presented above (Table 2) it is clear that a large amount of research has been produced on the adsorption of organic pollutants over the last years. However, a shortcoming of many of these studies is that most of them have been conducted in very ideal conditions. Typically, many studies have been conducted as batch assays under controlled laboratory conditions, like controlled temperature, focusing on single-component solutions prepared in pure water or, at best, using synthetically prepared wastewater.

The difference between batch feed and continuous flow hydraulics is an essential one as problems such as clogging of the filter media cannot be properly assessed from a batch assay, and the kinetics of the adsorption process may also substantially differ in the two conditions. Evaluation of multicomponent adsorption is also very important since wastewaters are typically very complex in their composition and, in such systems, the adsorbed amounts of a particular substance will unavoidably depend on the equilibrium between adsorption competition from all other substances. In addition, pollutant concentrations in these assays are frequently well above those typical of real environmental samples. Other far-fromreal conditions include the stirring of the solutions (whereas in realistic systems flow is very slow) and the very low ratio of adsorbent mass-to-volume of solution in comparison to typical ratios of real systems.

In many studies a single substance is often used to represent or model the behavior of a whole family of chemically related substances (or a big part of it). While in some cases such akin behavior may be observed and assumed, in general the validity of this assumption should be assessed as some traditional "family" denominations (e.g. pharmaceuticals) refer in fact to substances that vary considerably in structure and properties. Even when the chemical structures of the compounds present some similarity, that does not correspond necessarily to similar behavior in a particular process such as adsorption.

These batch experiments are useful, nevertheless, to highlight the potential applicability and selectivity of the materials, determine their adsorptive capacities and characterize the mechanisms, but, once these are established, research work must be conducted at larger scale under more realistic conditions to verify their viability in fully operational CWS.

For filter systems, one of the important factors in assessing their viability is the aspect of the lifetime of the adsorbent and the option between disposal or regeneration of the exhausted material. In CWS, the frequent disposal and renewal of the support matrix is practically unfeasible, which means that either desorption can be easily induced or the support matrix will, after a period of the system operation, saturate its adsorption capacity and lose this specific function in the CWS. The problem, however, may be less important in such cases where CWS are used as tertiary or quaternary treatment, when remaining pollutants to be retained in the treatment system are usually present at low concentrations and within a much less complex liquid matrix, after the wastewater being submitted to secondary treatment. In the case of CWS for treatment of specific types of industrial wastewaters, the extent of this problem is highly dependent on the pollutants load, but these specific wastewater types are frequently less complex and/or better defined in composition than domestic wastewaters.

Sorption studies conducted so far have revealed various options for materials (of very diverse nature and characteristics) with very similar adsorption capacities for the main groups of organic pollutants. Within a set of equivalently performing sorbents, it should be recalled however that the selection of materials is also based on other criteria as well, as has already been enunciated, namely the hydraulic properties, mechanical and chemical resistance, adequacy for supporting the development of plants and microorganisms, inertness, potential for release/leaching of additional contaminants, ability for desorption/regeneration, cost of the materials, etc. Cost is actually an important parameter in the comparison of adsorbent materials and, ultimately, in the viability assessment of otherwise technically attractive solutions. Cost is frequently associated with availability and requirements for processing/modifications of the materials. Recently, numerous approaches have been studied for the development of cheaper and effective adsorbents obtained from industrial and agricultural wastes and by-products, which may reveal promising developments in future research of CWS.

\section{Conclusion}

In constructed wetland systems the removal of pollutants from contaminated wastewater results from the cooperative and interdependent action of the three main components: support matrix, vegetation and microorganisms. Thus, system optimization may be achieved from a careful selection of each of these components but the effects of such component interdependences must not be overlooked. Still, there is ample opportunities for testing and selection, in particular, of the materials composing the support matrix of subsurface flow constructed wetlands. Especially in the case of the treatment of wastewaters contaminated with hardly biodegradable organics, where microorganisms cannot give an effective contribution, the role played by the support matrix, mainly through sorption processes, may be of major relevance.

In the past, the selection of support materials has focused on properties such as granulometry, porosity and hydraulic conductivity, and primary concerns were to provide adequate support for vegetation and prevent clogging of the system. With this underlying point of view, sand and gravel were the main traditional materials used. An increasing awareness of the benefits provided by sorbent materials has spurred in recent years an intensive research of other materials, aiming, among other goals, for the removal of organic xenobiotics from wastewaters.

Different materials have different characteristics, and thus different pollutant retention properties. The usefulness of a given adsorbent is determined by a compromise between hydraulic conductivity and adsorption capacity as determined by its surface area (a large hydraulic conductivity often precludes a large specific surface area of the substrate). Additional important factors determining the applicability of any material in constructed wetlands treatment, such as cost and local availability, saturation time and recyclability of saturated filter media, should be taken into consideration.

Activated carbon is one of the oldest and most popular choices for filter systems, but it has rarely been applied in constructed wetlands as it is generally considered to be an expensive material whose effectiveness, although high, does not justify its also rather high cost. Other options have mainly consisted of natural materials in a raw state or subjected to inexpensive treatment (either chemically modified or thermally and mechanically processed). One of the main criteria that is frequently presented to justify a particular 
choice is, in fact, the cost and wide availability of the material. Materials tested range from a variety of mineral sources and, recently, the class of industrial or agricultural wastes and by-products has also been gaining considerable popularity. Agro-wastes, due to their high carbon content, have also been increasingly used as lowcost precursors for the production of cheaper types of activated carbon.

Most studies have been conducted in batch and column studies at a laboratory scale and only very few have highlighted results on pilot or full-scale constructed wetland systems. Therefore, this active area of research in the field of the constructed wetlands phytotechnology does still require work to be carried out on large-scale systems to evaluate scaling-up effects on the efficiency and the kinetics, the behavior over longer periods of operation, the kinetics in different flow regimes, identification of problems such as clogging, etc. This type of study may be one of the most important lines of research to be pursued in the future in this area. But the laboratory scale experiments reported to date point to a variety of materials as potentially viable options for support matrix of more efficient constructed wetlands for organic xenobiotics removal. In addition, such type of experiments may still be useful for checking the efficiency of well-known materials in removing any new important pollutants that are continuously emerging in the list of substances of concern. Moreover, they are useful as simple preliminary screening assays to apply to new materials before any more laborious and complex studies are undertaken.

\section{References}

[1] K.Y. Bell, M.J.M. Wells, K.A. Traexler, M.L. Pellegrin, A. Morse, J. Bandy, Emerging pollutants, Water Environ. Res. 83 (2011) 1906-1984.

[2] K. Haarstad, H.J. Bavor, T. Maehlum, Organic and metallic pollutants in water treatment and natural wetlands: a review, Water Sci. Technol. 65 (2011) 76-99.

[3] A. Pal, K.Y.-H. Gin, A.Y.-C. Lin, M. Reinhard, Impacts of emerging organic contaminants on freshwater resources: Review of recent occurrences, sources, fate and effects, Sci. Total Environ. 408 (2010) 6062-6069.

[4] M. Gavrilescu, Fate of pesticides in the environment and its bioremediation, Eng. Life Sci. 5 (2005) 497-526.

[5] M.S. El Shahawi, A. Hamza, A.S. Bashammakh, W.T. Al Saggaf, An overview on the accumulation, distribution, transformations, toxicity and analytical methods for the monitoring of persistent organic pollutants, Talanta $80(2010)$ 1587-1597.

[6] K.C. Jones, P. de Voogt, Persistent organic pollutants (POPs): state of the science, Environ. Pollut. 100 (1999) 209-221.

[7] K. Fent, A.A. Weston, D. Caminada, Ecotoxicology of human pharmaceuticals, Aquat. Toxicol. 76 (2006) 122-159.

[8] T. Kosjek, S. Perko, M. Zupanc, M. Zanoški Hren, T. Landeka Dragicevic, D. Žigon, B. Kompare, E. Heath, Environmental occurrence, fate and transformation of benzodiazepines in water treatment, Water Res. 46 (2012) 355-368.

[9] D.J. Lapworth, N. Baran, M.E. Stuart, R.S. Ward, Emerging organic contaminants in groundwater: A review of sources, fate and occurrence, Environ. Pollut. 163 (2012) 287-303.

[10] D. Demirezen, A. Aksoy, K. Uruç, Effect of population density on growth biomass and nickel accumulation capacity of Lemna gibba (Lemnaceae), Chemosphere 66 (2007) 553-557.

[11] K. Peng, C. Luo, L. Lou, X. Li, Z. Shen, Bioaccumulation of heavy metals by the aquatic plants Potamogeton pectinatus L. and Potamogeton malaianus Miq. and their potential use for contamination indicators and in wastewater treatment, Sci. Total Environ. 392 (2008) 22-29.

[12] D. Barceló, M. Petrovic, Emerging Contaminants from Industrial and Municipal Waste. Ocurrence, Analysis and Effects, Springer-Verlag, Berlin, Germany, 2008

[13] UNEP, Status report on UNEP's and other related activities on persistent organic pollutants (POPs), Report num.: Status Report 15.03.1998, United Nations Environment Programme, Nairobi, Kenya, 1998.

[14] UNEP, Persistent Organic Pollutants, http://www.chem.unep.ch/pops/ (last accessed: 30-1-2013).

[15] J. Radjenovic, M. Petrovic, D. Barceló, Advanced mass spectrometric methods applied to the study of fate and removal of pharmaceuticals in wastewater treatment, Trac-Trends Anal. Chem. 26 (2007) 1132-1144.

[16] S.D. Kim, J. Cho, I.S. Kim, B.J. Vanderford, S.A. Snyder, Occurrence and removal of pharmaceuticals and endocrine disruptors in South Korean surface, drinking, and waste waters, Water Res. 41 (2007) 1013-1021.

[17] S. Esplugas, D.M. Bila, L.G. Krause, M. Dezotti, Ozonation and advanced oxidation technologies to remove endocrine disrupting chemicals (EDCs) and pharmaceuticals and personal care products (PPCPs) in water effluents, J. Hazard. Mater. 149 (2007) 631-642.

[18] S.A. Snyder, S. Adham, A.M. Redding, F.S. Cannon, J. DeCarolis, J. Oppenheimer, E.C. Wert, Y. Yoon, Role of membranes and activated carbon in the removal of endocrine disruptors and pharmaceuticals, Desalination 202 (2007) $156-181$.

[19] D.S. Aga, Fate of Pharmaceuticals in the Environment and in Water Treatment Systems, CRC Press, Boca Raton, FL, 2008.

[20] J. Benner, E. Salhi, T. Ternes, U. von Gunten, Ozonation of reverse osmosis concentrate: Kinetics and efficiency of beta blocker oxidation, Water Res. 42 (2008) 3003-3012

[21] S. Gan, E.V. Lau, H.K. Ng, Remediation of soils contaminated with polycyclic aromatic hydrocarbons (PAHs), J. Hazard. Mater. 172 (2009) 532-549.

[22] M. Doble, A. Kumar, Petroleum hydrocarbon pollution, Biotreatment of Industrial Effluents, Butterworth-Heinemann, Burlington, 2005 , pp. 241-253.

[23] W. Kit Chan, J. Jouët, S. Heng, K. Lun Yeung, J.C. Schrotter, Membrane contactor/separator for an advanced ozone membrane reactor for treatment of recalcitrant organic pollutants in water, J. Solid State Chem. 189 (2012) 96-100.

[24] S. Susarla, V.F. Medina, S.C. McCutcheon, Phytoremediation: An ecological solution to organic chemical contamination, Ecol. Eng. 18 (2002) 647-658.

[25] T. Macek, M. Mackova, J. Kas, Exploitation of plants for the removal of organics in environmental remediation, Biotechnol. Adv. 18 (2000) 23-34.

[26] B.Y. Zhang, J.S. Zheng, R.G. Sharp, Phytoremediation in engineered wetlands: Mechanisms and applications, Proc. Environ. Sci. 2 (2010) 1315-1325.

[27] A.C. Dietz, J.L. Schnoor, Advances in phytoremediation, Environ. Health Perspect. 109 (2001) 163-168.

[28] E. Pilon-Smits, Phytoremediation, Annu. Rev. Plant Biol. 56 (2005) 15-39.

[29] S. Eapen, S. Singh, S.F. D'Souza, Advances in development of transgenic plants for remediation of xenobiotic pollutants, Biotechnol. Adv. 25 (2007) 442-451.

[30] I. Alkorta, C. Garbisu, Phytoremediation of organic contaminants in soils, Bioresour. Technol. 79 (2001) 273-276.

[31] M. Mench, N. Lepp, V. Bert, J.P. Schwitzguébel, S.W. Gawronski, P. Schroder, J. Vangronsveld, Successes and limitations of phytotechnologies at field scale: Outcomes, assessment and outlook from COST Action 859, J. Soils Sediments 10 (2010) 1039-1070.

[32] B.V. Aken, P.A. Correa, J.L. Schnoor, Phytoremediation of polychlorinated biphenyls: New trends and promises, Environ. Sci. Technol. 44 (2010) 2767-2776.

[33] R. Olette, M. Couderchet, S. Biagianti, P. Eullaffroy, Toxicity and removal of pesticides by selected aquatic plants, Chemosphere 70 (2008) 1414-1421.

[34] J. Yu, W.Q. Chen, Y.H. Shui, J.Q. Liu, W.T. Ho, S.Y. Zhang, Research on wastewater treatment through integrated constructed wetlands, in: Proceedings of the 2011 International Conference on Multimedia Technology, ICMT 2011, Hangzhou, China, 2011, pp. 1197-1201.

[35] R.H. Kadlec, S.D. Wallace, Treatment Wetlands, second ed., CRC Press, Boca Raton, FL, USA, 2009.

[36] R. Haberl, S. Grego, G. Langergraber, R.H. Kadlec, A.R. Cicalini, S. Martins-Dias, J.M. Novais, S. Aubert, A. Gerth, H. Thomas, A. Hebner, Constructed wetlands for the treatment of organic pollutants, J. Soils Sediments 3 (2003) 109-124.

[37] J. García, D. Rousseau, J. Morató, E. Lesage, V. Matamoros, J. Bayona, Contaminant removal processes in subsurface-flow constructed wetlands: A review, Crit. Rev. Environ. Sci. Technol. 40 (2010) 561-661.

[38] G. Imfeld, M. Braeckevelt, P. Kuschk, H.H. Richnow, Monitoring and assessing processes of organic chemicals removal in constructed wetlands, Chemosphere 74 (2009) 349-362.

[39] J. Vymazal, L. Kröpfelová, Removal of organics in constructed wetlands with horizontal sub-surface flow: A review of the field experience, Sci. Total Environ. 407 (2009) 3911-3922.

[40] J.B. Williams, Phytoremediation in wetland ecosystems: progress, problems, and potential, Crit. Rev. Plant Sci. 21 (2002) 607-635.

[41] J.K. Grove, O.R. Stein, Polar organic solvent removal in microcosm constructed wetlands, Water Res. 39 (2005) 4040-4050.

[42] A. Dordio, A.J.P. Carvalho, D.M. Teixeira, C.B. Dias, A.P. Pinto, Removal of pharmaceuticals in microcosm constructed wetlands using Typha spp. and LECA, Bioresour. Technol. 101 (2010) 886-892.

[43] M. Hijosa-Valsero, V. Matamoros, R. Sidrach-Cardona, A. Pedescoll, J. Martin-Villacorta, J. Garcia, J.M. Bayona, E. Becares, Influence of design, physico-chemical and environmental parameters on pharmaceuticals and fragrances removal by constructed wetlands, Water Sci. Technol. 63 (2011) 2527-2534.

[44] V. Matamoros, J. García, J.M. Bayona, Organic micropollutant removal in a fullscale surface flow constructed wetland fed with secondary effluent, Water Res. 42 (2008) 653-660.

[45] D.Q. Zhang, S.K. Tan, R.M. Gersberg, S. Sadreddini, J. Zhu, N.A. Tuan, Removal of pharmaceutical compounds in tropical constructed wetlands, Ecol. Eng. 37 (2011) 460-464.

[46] C.S.C. Calheiros, A.O.S.S. Rangel, P.M.L. Castro, Treatment of industrial wastewater with two-stage constructed wetlands planted with Typha latifolia and Phragmites australis, Bioresour. Technol. 100 (2009) 3205-3213.

[47] A. Dordio, J. Pinto, A.P. Pinto, C.T. da Costa, A. Carvalho, D.M. Teixeira, Atenolol removal in microcosm constructed wetlands, Intern. J. Environ. Anal. Chem. 89 (2009) 835-848. 
[48] R. Budd, A. O'Geen, K.S. Goh, S. Bondarenko, J. Gan, Removal mechanisms and fate of insecticides in constructed wetlands, Chemosphere 83 (2011) 1581-1587.

[49] K.Tromp, A.T. Lima, A. Barendregt, J.T.A. Verhoeven, Retention of heavy metals and poly-aromatic hydrocarbons from road water in a constructed wetland and the effect of de-icing, J. Hazard. Mater. 203-204 (2012) 290-298.

[50] L.C. Davies, I.S. Pedro, R.A. Ferreira, F.G. Freire, J.M. Novais, S. Martins-Dias, Constructed wetland treatment system in textile industry and sustainable development, Water Sci. Technol. 58 (2008) 2017-2023.

[51] V. Matamoros, J. Puigagut, J. García, J.M. Bayona, Behavior of selected priority organic pollutants in horizontal subsurface flow constructed wetlands: A preliminary screening, Chemosphere 69 (2007) 1374-1380.

[52] K. Cai, C.T. Elliott, D.H. Phillips, M.L. Scippo, M. Muller, L. Connolly, Treatment of estrogens and androgens in dairy wastewater by a constructed wetland system, Water Res. 46 (2012) 2333-2343.

[53] J. Šíma, M. Havelka, V. Holcová, Removal of anionic surfactants from wastewater using a constructed wetland, Chem. Biodivers. 6 (2009) 1350-1363.

[54] D.A. Hammer, R.K. Bastian, Wetlands ecosystems: Natural water purifiers? in D.A. Hammer (Ed.), Constructed Wetlands for Wastewater Treatment, Lewis Publishers, Chelsea, MI, USA, 1989, pp. 5-19.

[55] USEPA, Subsurface flow constructed wetlands for wastewater treatment: A technology assessment, Report num.: EPA 832-R-93-008, Office of Wastewater Management, Washington, DC, USA, 1993.

[56] P.F. Cooper, G.D. Job, M.B. Green, R.B.E. Shutes, Reed Beds and Constructed Wetlands for Wastewater Treatment, WRc Publications, Medmenham, Marlow, UK, 1996.

[57] J. Vymazal, H. Brix, P.F. Cooper, M.B. Green, R. Haberl, Constructed Wetlands for Wastewater Treatment in Europe, Backhuys Publishers, Leiden, The Netherlands, 1998.

[58] M. Sundaravadivel, S. Vigneswaran, Constructed wetlands for wastewater treatment Crit. Rev. Environ. Sci. Technol. 31 (2001) 351-409.

[59] H. Brix, Functions of macrophytes in constructed wetlands, Water Sci. Technol. 29 (1994) 71-78.

[60] U. Stottmeister, A. Wiessner, P. Kuschk, U. Kappelmeyer, M. Kastner, O. Bederski, R.A. Muller, H. Moormann, Effects of plants and microorganisms in constructed wetlands for wastewater treatment, Biotechnol. Adv. 22 (2003) 93-117.

[61] USEPA and USDA-NRCS, A handbook of constructed wetlands. Volume 1: General considerations, USEPA Region III with USDA-NRCS, Washington, DC, USA 1995.

[62] J. Vymazal, The use constructed wetlands with horizontal sub-surface flow for various types of wastewater, Ecol. Eng. 35 (2009) 1-17.

[63] A.K. Choudhary, S. Kumar, C. Sharma, Constructed wetlands: An option for pulp and paper mill wastewater treatment, Electron. J. Environ. Agric. Food Chem. 10 (2011) 3023-3037.

[64] D. Low, K. Tan, T. Anderson, G.P. Cobb, J. Liu, W.A. Jackson, Treatment of RDX using down-flow constructed wetland mesocosms, Ecol. Eng. 32 (2008) $72-80$.

[65] M.S. Fountoulakis, S. Terzakis, N. Kalogerakis, T. Manios, Removal of polycyclic aromatic hydrocarbons and linear alkylbenzene sulfonates from domestic wastewater in pilot constructed wetlands and a gravel filter, Ecol. Eng. 35 (2009) 1702-1709.

[66] E.M. Seeger, P. Kuschk, H. Fazekas, P. Grathwohl, M. Kaestner, Bioremediation of benzene-, MTBE- and ammonia-contaminated groundwater with pilot-scale constructed wetlands, Environ. Pollut. 159 (2011) 3769-3776.

[67] P. Chris Wilson, H. Lu, Y. Lin, Norflurazon and simazine removal from surface water using a constructed wetland, Bull. Environ. Contam. Toxicol. 87 (2011) 426-430.

[68] S.A. Ong, K. Uchiyama, D. Inadama, K. Yamagiwa, Simultaneous removal of color, organic compounds and nutrients in azo dye-containing wastewater using up-flow constructed wetland, J. Hazard. Mater. 165 (2009) 696-703.

[69] E. Ranieri, P. Verlicchi, T.M. Young, Paracetamol removal in subsurface flow constructed wetlands, J. Hydrol. 404 (2011) 130-135.

[70] M. Breitholtz, M. Näslund, D. Stråe, H. Borg, R. Grabic, J. Fick, An evaluation of free water surface wetlands as tertiary sewage water treatment of micropollutants, Ecotox. Environ. Safe. 78 (2012) 63-71.

[71] V. Matamoros, C. Arias, H. Brix, J. Bayona, Preliminary screening of small-scale domestic wastewater treatment systems for removal of pharmaceutical and personal care products, Water Res. 43 (2009) 55-62.

[72] K.R. Reddy, R.D. DeLaune, Toxic Organic Compounds, Biogeochemistry of Wetlands: Science and Applications, CRC, Press, Boca Raton, FL, 2008, pp. 507-536.

[73] J. Vymazal, Plants used in constructed wetlands with horizontal subsurface flow: A review, Hydrobiologia 674 (2011) 133-156.

[74] A.V. Dordio, J. Teimao, I. Ramalho, A.J.P. Carvalho, A.J.E. Candeias, Selection of a support matrix for the removal of some phenoxyacetic compounds in constructed wetlands systems, Sci. Total Environ. 380 (2007) 237-246.

[75] A.V. Dordio, A.J.E. Candeias, A.P. Pinto, C.T. da Costa, A.J.P. Carvalho, Preliminary media screening for application in the removal of clofibric acid carbamazepine and ibuprofen by SSF-constructed wetlands, Ecol. Eng. 35 (2009) 290-302.

[76] J. García, J. Chiva, P. Aguirre, E. Álvarez, J.P. Sierra, R. Mujeriego, Hydraulic behaviour of horizontal subsurface flow constructed wetlands with different aspect ratio and granular medium size, Ecol. Eng. 23 (2004) 177-187.
[77] J. Brisson, F. Chazarenc, Maximizing pollutant removal in constructed wetlands: Should we pay more attention to macrophyte species selection? Sci. Total Environ. 407 (2009) 3923-3930.

[78] C.A. Prochaska, A.I. Zouboulis, K.M. Eskridge, Performance of pilot-scale vertical-flow constructed wetlands, as affected by season, substrate, hydraulic load and frequency of application of simulated urban sewage, Ecol. Eng. 31 (2007) 57-66.

[79] H. Brix, C.A. Arias, M. del Bubba, Media selection for sustainable phosphorus removal in subsurface flow constructed wetlands, Water Sci. Technol. 44 (2001) 47-54

[80] C.S. Akratos, V.A. Tsihrintzis, Effect of temperature, HRT, vegetation and porous media on removal efficiency of pilot-scale horizontal subsurface flow constructed wetlands, Ecol. Eng. 29 (2007) 173-191.

[81] M. Li, Q. Zhou, M. Tao, Y. Wang, L. Jiang, Z. Wu, Comparative study of microbial community structure in different filter media of constructed wetland, J. Environ. Sci. 22 (2010) 127-133.

[82] M. Truu, J. Juhanson, J. Truu, Microbial biomass, activity and community composition in constructed wetlands, Sci. Total Environ. 407 (2009) 3958-3971.

[83] C.S.C. Calheiros, A.F. Duque, A. Moura, I.S. Henriques, A. Correia, A.O.S.S Rangel, P.M.L. Castro, Substrate effect on bacterial communities from constructed wetlands planted with Typha latifolia treating industrial wastewater, Ecol. Eng. 35 (2009) 744-753.

[84] A. Albuquerque, J. Oliveira, S. Semitela, L. Amaral, Evaluation of the effectiveness of horizontal subsurface flow constructed wetlands for different media, J. Environ. Sci. 22 (2010) 820-825.

[85] A.V. Dordio, P. Gonçalves, D. Teixeira, A.J.E. Candeias, J.E. Castanheiro, A.P. Pinto, A.J.P. Carvalho, Pharmaceuticals sorption behaviour in granulated cork for the selection of a support matrix for a constructed wetlands system, Intern. J. Environ. Anal. Chem. 91 (2011) 615-631.

[86] J. Vymazal, Horizontal sub-surface flow and hybrid constructed wetlands systems for wastewater treatment, Ecol. Eng. 25 (2005) 478-490.

[87] H. Brix, Do macrophytes play a role in constructed treatment wetlands? Water Sci. Technol. 35 (1997) 11-17.

[88] M. Dua, A. Singh, N. Sethunathan, A. Johri, Biotechnology and bioremediation: successes and limitations, Appl. Microbiol. Biotechnol. 59 (2002) 143-152.

[89] J.L. Seffernick, L.P. Wackett, Rapid evolution of bacterial catabolic enzymes: A case study with atrazine chlorohydrolase, Biochemistry 40 (2001) 12747-12753.

[90] S. Salomo, C. Münch, I. Röske, Evaluation of the metabolic diversity of microbial communities in four different filter layers of a constructed wetland with vertical flow by Biolog ${ }^{\mathrm{TM}}$ analysis, Water Res. 43 (2009) 4569-4578.

[91] F. Korte, G. Kvesitadze, D. Ugrekhelidze, M. Gordeziani, G. Khatisashvili, O. Buadze, G. Zaalishvili, F. Coulston, Organic toxicants and plants, Ecotox. Environ. Safe. 47 (2000) 1-26.

[92] C. Collins, M. Fryer, A. Grosso, Plant uptake of non-ionic organic chemicals, Environ. Sci. Technol. 40 (2006) 45-52.

[93] K.E. Gerhardt, X.D. Huang, B.R. Glick, B.M. Greenberg, Phytoremediation and rhizoremediation of organic soil contaminants: Potential and challenges, Plant Sci. 176 (2009) 20-30.

[94] P.C. Abhilash, S. Jamil, N. Singh, Transgenic plants for enhanced biodegradation and phytoremediation of organic xenobiotics, Biotechnol. Adv. 27 (2009) 474-488.

[95] P. Schroder, C. Collins, Conjugating enzymes involved in xenobiotic metabolism of organic xenobiotics in plants, Int. J. Phytoremediat. 4 (2002) 247-265.

[96] Q. Chaudhry, P. Schröder, D. Werck-Reichhart, W. Grajek, R. Marecik, Prospects and limitations of phytoremediation for the removal of persistent pesticides in the environment, Environ. Sci. Pollut. Res. 9 (2002) $4-17$.

[97] J. Coleman, C. Frova, P. Schröder, M. Tissut, Exploiting plant metabolism for the phytoremediation of persistent herbicides, Environ. Sci. Pollut. Res. 9 (2002) $18-28$.

[98] D.E. Salt, R.D. Smith, I. Raskin, Phytoremediation, Annu. Rev. Plant Physiol Plant Mol. Biol. 49 (1998) 643-668.

[99] N.K. Hannink, S.J. Rosser, N.C. Bruce, Phytoremediation of explosives, Crit. Rev. Plant Sci. 21 (2002) 511-538

[100] A.V. Dordio, M. Belo, D.M. Teixeira, A.J.P. Carvalho, C.M.B. Dias, Y. Picó, A.P. Pinto, Evaluation of carbamazepine uptake and metabolization by Typha spp. a plant with potential use in phytotreatment, Bioresour. Technol. 102 (2011) 7827-7834.

[101] R. Bhadra, D.G. Wayment, J.B. Hughes, J.V.Shanks, Confirmation of conjugation processes during TNT metabolism by axenic plant roots, Environ. Sci. Technol. 33 (1998) 446-452.

[102] Y.L. Yu, Y.X. Chen, Y.M. Luo, X.D. Pan, Y.F. He, M.H. Wong, Rapid degradation of butachlor in wheat rhizosphere soil, Chemosphere 50 (2003) 771-774.

[103] H. Sun, J. Xu, S. Yang, G. Liu, S. Dai, Plant uptake of aldicarb from contaminated soil and its enhanced degradation in the rhizosphere, Chemosphere 54(2004) 569-574.

[104] M. Scholz, B.h. Lee, Constructed wetlands: a review, Int. J. Environ. Stud. 62 (2005) 421-447.

[105] B. Dhir, P. Sharmila, P.P. Saradhi, Potential of aquatic macrophytes for removing contaminants from the environment, Crit. Rev. Environ. Sci. Technol. 39 (2009) 754-781.

[106] E.P.H. Best, M.E. Zappi, H.L. Fredrickson, S.L. Sprecher, S.L. Larson, M. Ochman, Screening of aquatic and wetland plant species for phytoremediation of 
explosives-contaminated groundwater from the Iowa Army Ammunition Plant, Ann. N. Y. Acad. Sci. 829 (1997) 179-194.

[107] E.P.H. Best, S.L. Sprecher, S.L. Larson, H.L. Fredrickson, D.F. Bader, Environmental behavior of explosives in groundwater from the Milan Army Ammunition Plant in aquatic and wetland plant treatments. Uptake and fate of TNT and RDX in plants, Chemosphere 39 (1999) 2057-2072.

[108] E. Gikas, N.G. Papadopoulos, F.N. Bazoti, G. Zalidis, A. Tsarbopoulos, Use of liquid chromatography/electrospray ionization tandem mass spectrometry to study the degradation pathways of terbuthylazine (TER) by Typha latifolia in constructed wetlands: identification of a new TER metabolite, Rapid Commun. Mass Spectrom. 26 (2012) 181-188.

[109] A. Amaya-Chavez, L. Martinez-Tabche, E. Lopez-Lopez, M. Galar-Martinez, Methyl parathion toxicity to and removal efficiency by Typha latifolia in water and artificial sediments, Chemosphere 63 (2006) 1124-1129.

[110] P. Schröder, D. Daubner, H. Maier, J. Neustifter, R. Debus, Phytoremediation of organic xenobiotics-Glutathione dependent detoxification in Phragmites plants from European treatment sites, Bioresour. Technol. 99 (2008) 7183-7191.

[111] A.V. Dordio, C. Duarte, M. Barreiros, A.J.P. Carvalho, A.P. Pinto, C.T. da Costa Toxicity and removal efficiency of pharmaceutical metabolite clofibric acid by Typha spp.-Potential use for phytoremediation? Bioresour. Technol. 100 (2009) 1156-1161.

[112] A. Dordio, R. Ferro, D. Teixeira, A.J.P. Carvalho, A.P. Pinto, C.M.B. Dias, Study on the use of Typha spp. for the phytotreatment of water contaminated with ibuprofen, Intern. J. Environ. Anal. Chem. 91 (2011) 654-667.

[113] A.B.A. Boxall, P. Johnson, E.J. Smith, C.J. Sinclair, E. Stutt, L.S. Levy, Uptake of veterinary medicines from soils into plants, J. Agric. Food Chem. 54 (2006) 2288-2297.

[114] W.D. Kong, Y.G. Zhu, Y.C. Liang, J. Zhang, F.A. Smith, A. Yang, Uptake of oxytetracycline and its phytotoxicity to alfalfa (Medicago sativa L.), Environ. Pollut. 147 (2007) 187-193.

[115] P.A. Herklotz, P. Gurung, B.V. Heuvel, C.A. Kinney, Uptake of human pharmaceuticals by plants grown under hydroponic conditions, Chemosphere 78 (2010) 1416-1421.

[116] USEPA, Wastewater technology fact sheet wetlands: Subsurface flow, Report num.: EPA 832-F-00-023, Office of Wastewater Management, Washington, DC, USA, 2000

[117] Y. Wen, C. Xu, G. Liu, Y. Chen, Q. Zhou, Enhanced nitrogen removal reliability and efficiency in integrated constructed wetland microcosms using zeolite, Front. Environ. Sci. Eng. China 6 (2012) 140-147.

[118] R. Netter, Flow characteristics of planted soil filters, Water Sci. Technol. 29 (1994) 37-44.

[119] K.R. Reddy, R.D. DeLaune, Biogeochemistry of Wetlands: Science and Applications, CRC Press, Boca Raton, FL, USA, 2008.

[120] K. Muller, G.N. Magesan, N.S. Bolan, A critical review of the influence of effluent irrigation on the fate of pesticides in soil, Agric. Ecosyst. Environ. 120 (2007) 93-116.

[121] J. Tolls, Sorption of veterinary pharmaceuticals in soils: A review, Environ. Sci. Technol. 35 (2001) 3397-3406.

[122] J. Kyziol-Komosinska, C. Rosik-Dulewska, M. Pajak, M. Jarzyna, Removal of direct dyes from wastewater by sorption onto smectite-clay, Arch. Environ. Prot. 36 (2010) 3-14.

[123] Z. Klika, P. Pustkova, M. Dudova, P. Capkova, C. Klikova, T. Matys Grygar, The adsorption of methylene blue on montmorillonite from acid solutions, Clay Min. 46 (2011) 461-471

[124] Z.G. Pei, J.J. Kong, X.Q. Shan, B. Wen, Sorption of aromatic hydrocarbons onto montmorillonite as affected by norfloxacin, J. Hazard. Mater. 203 (2012) 137-144.

[125] T.R. Pereira, D.A. Laird, C.T. Johnston, B.J. Teppen, H. Li, S.A. Boyd, Mechanism of dinitrophenol herbicide sorption by smectites in aqueous suspensions at varying pH, Soil Sci. Soc. Am. J. 71 (2007) 1476-1481.

[126] L. Johansson, The use of Leca (Light Expanded Clay Aggregrates) for the removal of phosphorus from wastewater, Water Sci. Technol. 35 (1997) 87-93.

[127] T. Zhu, P.D. Jenssen, T. Mæhlum, T. Krogstad, Phosphorus sorption and chemical characteristics of lightweight aggregates (LWA) - potential filter media in treatment wetlands, Water Sci. Technol. 35 (1997) 103-108.

[128] A. Drizo, C.A. Frost, J. Grace, K.A. Smith, Physico-chemical screening of phosphate-removing substrates for use in constructed wetland systems, Water Res. 33 (1999) 3595-3602.

[129] A. Drizo, C.A. Frost, K.A. Smith, J. Grace, Phosphate and ammonium removal by constructed wetlands with horizontal subsurface flow, using shale as a substrate, Water Sci. Technol. 35 (1997) 95-102.

[130] L. Gervin, H. Brix, Removal of nutrients from combined sewer overflows and lake water in a vertical-flow constructed wetland system, Water Sci. Technol. 44 (2001) 171-176.

[131] H. Wang, X.W. He, T.Q. Liu, C.H. Zhang, Analysis on the adsorptive characteristics for ammonia nitrogen and phosphorus of different substrates in constructed wetlands, Fresenius Environ. Bull. 20 (2011) 2890-2895.

[132] D.F. Xu, J.M. Xu, J.J. Wu, A. Muhammad, Studies on the phosphorus sorption capacity of substrates used in constructed wetland systems, Chemosphere 63 (2006) 344-352.

[133] C. Vohla, M. Kõiv, H.J. Bavor, F. Chazarenc, Ü. Mander, Filter materials for phosphorus removal from wastewater in treatment wetlands-A review, Ecol. Eng. 37 (2011) 70-89.
[134] D.J. Ballantine, C.C. Tanner, Substrate and filter materials to enhance phosphorus removal in constructed wetlands treating diffuse farm runoff: a review, N. Z. J. Agric. Res. 53 (2010) 71-95.

[135] V. Cucarella, G. Renman, Phosphorus sorption capacity of filter materials used for on-site wastewater treatment determined in batch experiments-A comparative study, J. Environ. Qual. 38 (2009) 381-392.

[136] L.J. Westholm, Substrates for phosphorus removal-Potential benefits for onsite wastewater treatment? Water Res. 40 (2006) 23-36.

[137] S. Babel, T.A. Kurniawan, Low-cost adsorbents for heavy metals uptake from contaminated water: a review, J. Hazard. Mater. 97 (2003) 219-243.

[138] F. Derbyshire, M. Jagtoyen, R. Andrews, A. Rao, I. Martin-Gullon, E.A. Grulke, Carbon materials in environmental applications, Chem. Phys. Carb. 27 (2001) $1-66$.

[139] K.R. Ramakrishna, T. Viraraghavan, Dye removal using low cost adsorbents, Water Sci. Technol. 36 (1997) 189-196.

[140] Y. Chen, Y. Zhu, Z. Wang, Y. Li, L. Wang, L. Ding, X. Gao, Y. Ma, Y. Guo, Application studies of activated carbon derived from rice husks produced by chemical-thermal process-A review, Adv. Colloid Interface Sci. 163 (2011) 39-52.

[141] A.A. Attia, B.S. Girgis, N.A. Fathy, Removal of methylene blue by carbons derived from peach stones by $\mathrm{H}_{3} \mathrm{PO}_{4}$ activation: Batch and column studies, Dyes Pigment. 76 (2008) 282-289.

[142] N. Kannan, M.M. Sundaram, Kinetics and mechanism of removal of methylene blue by adsorption on various carbons-a comparative study, Dyes Pigment. 51 (2001) 25-40.

[143] Y.S. Al Degs, M.I. El Barghouthi, A.H. El Sheikh, G.A. Walker, Effect of solution $\mathrm{pH}$, ionic strength, and temperature on adsorption behavior of reactive dyes on activated carbon, Dyes Pigment. 77 (2008) 16-23.

[144] R. Jain, M. Mathur, S. Sikarwar, A. Mittal, Removal of the hazardous dye rhodamine B through photocatalytic and adsorption treatments, J. Environ. Manage. 85 (2007) 956-964.

[145] S.B. Wang, Z.H. Zhu, Effects of acidic treatment of activated carbons on dye adsorption, Dyes Pigment. 75 (2007) 306-314.

[146] V. Meshko, L. Markovska, M. Mincheva, A.E. Rodrigues, Adsorption of basic dyes on granular activated carbon and natural zeolite, Water Res. 35 (2001) 3357-3366.

[147] G.C. Lu, J. Hao, L. Liu, H.W. Ma, Q.F. Fang, L.M. Wu, M.Q. Wei, Y.H. Zhang, The adsorption of phenol by lignite activated carbon, Chin. J. Chem. Eng. 19(2011) 380-385.

[148] J.M.V. Nabais, J.A. Gomes, Suhas, P.J.M. Carrott, C. Laginhas, S. Roman, Phenol removal onto novel activated carbons made from lignocellulosic precursors: Influence of surface properties, J. Hazard. Mater. 167 (2009) 904-910.

[149] B.H. Hameed, A.A. Rahman, Removal of phenol from aqueous solutions by adsorption onto activated carbon prepared from biomass material, J. Hazard. Mater. 160 (2008) 576-581.

[150] J.M. Salman, B.H. Hameed, Removal of insecticide carbofuran from aqueous solutions by banana stalks activated carbon, J. Hazard. Mater. 176 (2010) 814-819.

[151] J.M. Salman, B.H. Hameed, Adsorption of 2,4-dichlorophenoxyacetic acid and carbofuran pesticides onto granular activated carbon, Desalination 256 (2010) 129-135.

[152] A. Jusoh, W.J.H. Hartini, N. Ali, A. Endut, Study on the removal of pesticide in agricultural run off by granular activated carbon, Bioresour. Technol. 102 (2011) 5312-5318.

[153] R. Boussahel, H. Irinislimane, D. Harik, K.M. Moussaoui, Adsorption, kinetics, and equilibrium studies on removal of 4,4-DDT from aqueous solutions using low-cost adsorbents, Chem. Eng. Commun. 196 (2009) 1547-1558.

[154] V.E. Domingues, G. Priolo, A.C. Alves, M.E. Cabral, C. Delerue-Matos, Adsorption behavior of alpha-cypermethrin on cork and activated carbon, J. Environ. Sci. Health Part B-Pestic. Contam. Agric. Wastes 42 (2007) 649-654.

[155] A.S. Mestre, J. Pires, J.M.F. Nogueira, A.P. Carvalho, Activated carbons for the adsorption of ibuprofen, Carbon 45 (2007) 1979-1988.

[156] A.S. Mestre, M.L. Pinto, J. Pires, J.M.F. Nogueira, A.P. Carvalho, Effect of solution $\mathrm{pH}$ on the removal of clofibric acid by cork-based activated carbons, Carbon 48 (2010) 972-980.

[157] S.K. Behera, S.Y. Oh, H.S. Park, Sorptive removal of ibuprofen from water using selected soil minerals and activated carbon, Int. J. Environ. Sci. Technol. 9 (2012) 85-94.

[158] S. Beninati, D. Semeraro, M. Mastragostino, Adsorption of paracetamol and acetylsalicylic acid onto commercial activated carbons, Adsorp. Sci. Technol. 26 (2008) 721-734.

[159] V. Marinovic, M. Ristic, M. Dostanic, Dynamic adsorption of trinitrotoluene on granular activated carbon, J. Hazard. Mater. 117 (2005) 121-128.

[160] H. Hindarso, S. Ismadji, F. Wicaksana, Mudjijati, N. Indraswati, Adsorption of benzene and toluene from aqueous solution onto granular activated carbon, J. Chem. Eng. Data 46 (2001) 788-791.

[161] G.F. Liu, J. Ma, X.C. Li, Q.D. Qin, Adsorption of bisphenol A from aqueous solution onto activated carbons with different modification treatments, J. Hazard. Mater. 164 (2009) 1275-1280.

[162] F. Rodriguez-Reinoso, Activated carbon: Structure characterization preparation and applications, in: H. Marsh, E.A. Heintz, F. Rodriguez-Reinoso (Eds.), Introduction to Carbon Technologies, Universidad de Alicante, Alicante, Spain, 1997. 
[163] M. Scholz, J. Xu, H.I. Dodson, Comparison of filter media, plant communities and microbiology within constructed wetlands treating wastewater containing heavy metals, J. Chem. Technol. Biotechnol. 76 (2001) 827-835.

[164] Y. Ren, B. Zhang, Z. Liu, J. Wang, Optimization of four kinds of constructed wetlands substrate combination treating domestic sewage, Wuhan Univ. J. Nat. Sci. 12 (2007) 1136-1142.

[165] M. Scholz, J. Xu, Comparison of constructed reed beds with different filter media and macrophytes treating urban stream water contaminated with lead and copper, Ecol. Eng. 18 (2002) 385-390.

[166] M. Streat, J.W. Patrick, M.J.C. Perez, Sorption of phenol and para-chlorophenol from water using conventional and novel activated carbons, Water Res. 29 (1995) 467-472.

[167] T. Shichi, K. Takagi, Clay minerals as photochemical reaction fields, J. Photochem. Photobiol. C Photochem. Rev. 1 (2000) 113-130.

[168] K.G. Bhattacharyya, S. Sen Gupta, Adsorption of a few heavy metals on natural and modified kaolinite and montmorillonite: A review, Adv. Colloid Interface Sci. 140 (2008) 114-131.

[169] M. Rafatullah, O. Sulaiman, R. Hashim, A. Ahmad, Adsorption of methylene blue on low-cost adsorbents: A review, J. Hazard. Mater. 177 (2010) 70-80.

[170] S.A. Boyd, G.Y. Sheng, B.J. Teppen, C.J. Johnston, Mechanisms for the adsorption of substituted nitrobenzenes by smectite clays, Environ. Sci. Technol. 35 (2001) 4227-4234.

[171] H. Li, B.J. Teppen, C.T. Johnston, S.A. Boyd, Thermodynamics of nitroaromatic compound adsorption from water by smectite clay, Environ. Sci. Technol. 38 (2004) 5433-5442.

[172] C.P. Wang, Y.J. Ding, B.J. Teppen, S.A. Boyd, C.Y. Song, H. Li, Role of Interlayer Hydration in Lincomycin Sorption by Smectite Clays, Environ. Sci. Technol. 43 (2009) 6171-6176.

[173] G.Y. Sheng, C.T. Johnston, B.J. Teppen, S.A. Boyd, Adsorption of dinitrophenol herbicides from water by montmorillonites, Clay Clay Min. 50 (2002) 25-34.

[174] C.T. Johnston, M.F. De Oliveira, B.J. Teppen, G.Y. Sheng, S.A. Boyd, Spectroscopic study of nitroaromatic-smectite sorption mechanisms, Environ. Sci. Technol. 35 (2001) 4767-4772.

[175] W.H. Zhang, Y.J. Ding, S.A. Boyd, B.J. Teppen, H. Li, Sorption and desorption of carbamazepine from water by smectite clays, Chemosphere 81 (2010) 954-960.

[176] R.A. Figueroa, A. Leonard, A.A. Mackay, Modeling tetracycline antibiotic sorption to clays, Environ. Sci. Technol. 38 (2004) 476-483.

[177] Z.H. Li, P.H. Chang, W.T. Jiang, J.S. Jean, H.L. Hong, L.B. Liao, Removal of diphenhydramine from water by swelling clay minerals, J. Colloid Interface Sci. 360 (2011) 227-232.

[178] R.M.T. Sanchez, M.J. Genet, E.M. Gaigneaux, M.D. Afonso, S. Yunes, Benzimidazole adsorption on the external and interlayer surfaces of raw and treated montmorillonite, Appl. Clay Sci. 53 (2011) 366-373.

[179] Y. Park, G.A. Ayoko, R.L. Frost, Application of organoclays for the adsorption of recalcitrant organic molecules from aqueous media, J. Colloid Interface Sci. 354 (2011) 292-305.

[180] Q. Zhou, R.L. Frost, H. He, Y. Xi, M. Zbik, TEM, XRD, and thermal stability of adsorbed paranitrophenol on DDOAB organoclay, J. Colloid Interface Sci. 311 (2007) 24-37.

[181] S.A. Boyd, S. Shaobai, J.F. Lee, M.M. Mortland, Pentachlorophenol sorption by organo-clays, Clay Clay Min. 36 (1988) 125-130.

[182] M. Alkan, Ö. Demirba, S. Çelikçapa, M. Dogan, Sorption of acid red 57 from aqueous solution onto sepiolite, J. Hazard. Mater. 116 (2004) 135-145.

[183] A. Rodriguez, G. Ovejero, M. Mestanza, J. Garcia, Removal of dyes from wastewaters by adsorption on sepiolite and pansil, Ind. Eng. Chem. Res. 49 (2010) 3207-3216

[184] B. Karagozoglu, M. Tasdemir, E. Demirbas, M. Kobya, The adsorption of basic dye (Astrazon Blue FGRL) from aqueous solutions onto sepiolite, fly ash and apricot shell activated carbon: Kinetic and equilibrium studies, J. Hazard. Mater. 147 (2007) 297-306.

[185] M. Alkan, S. Celikcapa, O. Demirbas, M. Dogan, Removal of reactive blue 221 and acid blue 62 anionic dyes from aqueous solutions by sepiolite, Dyes Pigment. 65 (2005) 251-259.

[186] E. Eren, B. Afsin, Investigation of a basic dye adsorption from aqueous solution onto raw and pre-treated sepiolite surfaces, Dyes Pigment. 73 (2007) $162-167$.

[187] M. Ugurlu, Adsorption of a textile dye onto activated sepiolite, Microporous Mesoporous Mater. 119 (2009) 276-283.

[188] Y.S. Choi, J.H. Cho, Color removal from dye wastewater using vermiculite, Environ. Technol. 17 (1996) 1169-1180.

[189] L.F. Zhu, R.L. Zhu, Simultaneous adsorption of malachite green and hydrophobic organic compounds onto bentonite, Fresenius Environ. Bull. 20 (2011) 521-527.

[190] G.L. da Silva, V.L. Silva, M.G.A. Vieira, M.G.C. da Silva, Solophenyl navy blue dye removal by smectite clay in a porous bed column, Adsorpt. Sci. Technol. 27 (2009) 861-875.

[191] L. Zhu, J. Ma, Simultaneous removal of acid dye and cationic surfactant from water by bentonite in one-step process, Chem. Eng. J. 139 (2008) 503-509.

[192] X.J. Peng, J. Wang, B. Fan, Z.K. Luan, Sorption of endrin to montmorillonite and kaolinite clays, J. Hazard. Mater. 168 (2009) 210-214.

[193] S. Hengpraprom, C.M. Lee, J.T. Coates, Sorption of humic acids and alphaendosulfan by clay minerals, Environ. Toxicol. Chem. 25 (2006) 11-17.

[194] S. Polati, S. Angioi, V. Gianotti, F. Gosetti, M.C. Gennaro, Sorption of pesticides on kaolinite and montmorillonite as a function of hydrophilicity, J. Environ. Sci. Health Part B Pestic. Contam. Agric. Wastes 41 (2006) 333-344.
[195] G. Abate, J.C. Masini, Sorption of atrazine, propazine, deethylatrazine, deisopropylatrazine and hydroxyatrazine onto organovermiculite, J. Braz. Chem. Soc. 16 (2005) 936-943.

[196] A. Baglieri, D. Borzi, C. Abbate, M. Negre, M. Gennari, Removal of fenhexamid and pyrimethanil from aqueous solutions by clays and organoclays, J. Environ. Sci. Health Part B-Pestic. Contam. Agric. Wastes 44 (2009) 220-225.

[197] S. Changchaivong, S. Khaodhiar, Adsorption of naphthalene and phenanthrene on dodecylpyridinium-modified bentonite, Appl. Clay Sci. 43 (2009) 317-321.

[198] S. Polati, F. Gosetti, V. Gianotti, M.C. Gennaro, Sorption and desorption behavior of chloroanilines and chlorophenols on montmorillonite and kaolinite, J. Environ. Sci. Health Part B Pestic. Contam. Agric. Wastes 41 (2006) 765-779.

[199] S.A. White, M.D. Taylor, J.P. Albano, T. Whitwell, S.J. Klaine, Phosphorus retention in lab and field-scale subsurface-flow wetlands treating plant nursery runoff, Ecol. Eng. 37 (2011) 1968-1976.

[200] D.M.R. Mateus, H.J.O. Pinho, Phosphorus removal by expanded clay-six years of pilot-scale constructed wetlands experience, Water Environ. Res. 82 (2010) 128-137.

[201] C.S.C. Calheiros, A.O.S.S. Rangel, P.M.L. Castro, Evaluation of different substrates to support the growth of Typha latifolia in constructed wetlands treating tannery wastewater over long-term operation, Bioresour. Technol. 99 (2008) 6866-6877.

[202] M. Scholz, J. Xu, Performance comparison of experimental constructed wetlands with different filter media and macrophytes treating industrial wastewater contaminated with lead and copper, Bioresour. Technol. 83 (2002) 71-79.

[203] N. Farahbakhshazad, G.M. Morrison, Phosphorus removal in a vertical upflow constructed wetland system, Water Sci. Technol. 48 (2003) 43-50.

[204] M. Oovel, A. Tooming, T. Mauring, U. Mander, Schoolhouse wastewater purification in a LWA-filled hybrid constructed wetland in Estonia, Ecol. Eng. 29 (2007) $17-26$

[205] F. Suliman, H. French, L.E. Haugen, B. Klove, P. Jenssen, The effect of the scale of horizontal subsurface flow a constructed wetlands on flow and transport parameters, Water Sci. Technol. 51 (2005) 259-266.

[206] L. Amado, A. Albuquerque, A.E. Santo, Influence of stormwater infiltration on the treatment capacity of a LECA-based horizontal subsurface flow constructed wetland, Ecol. Eng. 39 (2012) 16-23.

[207] S.B. Wang, Y.L. Peng, Natural zeolites as effective adsorbents in water and wastewater treatment, Chem. Eng. J. 156 (2010) 11-24.

[208] S. Razee, T. Masujima, Uptake monitoring of anilines and phenols using modified zeolites, Anal. Chim. Acta 464 (2002) 1-5.

[209] P. Huttenloch, K.E. Roehl, K. Czurda, Sorption of nonpolar aromatic contaminants by chlorosilane surface modified natural minerals, Environ. Sci. Technol. 35 (2001) 4260-4264.

[210] Z.H. Li, T. Burt, R.S. Bowman, Sorption of ionizable organic solutes by surfactant modified zeolite, Environ. Sci. Technol. 34 (2000) 3756-3760.

[211] M. Ghiaci, A. Abbaspur, R. Kia, F. Seyedeyn-Azad, Equilibrium isotherm studies for the sorption of benzene, toluene, and phenol onto organo-zeolites and as-synthesized MCM-41, Sep. Purif. Technol. 40 (2004) 217-229.

[212] A. Kuleyin, Removal of phenol and 4-chlorophenol by surfactant-modified natural zeolite, J. Hazard. Mater. 144 (2007) 307-315.

[213] B. Armagan, O. Ozdemir, M. Turan, M.S. Celik, The removal of reactive azo dyes by natural and modified zeolites, J. Chem. Technol. Biotechnol. 78 (2003) 725-732.

[214] O. Ozdemir, B. Armagan, M. Turan, M.S. Celik, Comparison of the adsorption characteristics of azo-reactive dyes on mezoporous minerals, Dyes Pigment. 62 (2004) 49-60.

[215] R.P. Han, J.J. Zhang, P. Han, Y.F. Wang, Z.H. Zhao, M.S. Tang, Study of equilibrium, kinetic and thermodynamic parameters about methylene blue adsorption onto natural zeolite, Chem. Eng. J. 145 (2009) 496-504.

[216] A. Dakovic, M. Tomasevic-Canovic, G. Rottinghaus, V. Dondur, Z. Masic, Adsorption of ochratoxin A on octadecyldimethyl benzyl ammonium exchanged-clinoptilolite-heulandite tuff, Colloid Surf. B Biointerfaces 30 (2003) 157-165.

[217] A. Dakovic, M. Tomasevic-Canovic, G.E. Rottinghaus, S. Matijasevic, Z. Sekulic Fumonisin B-1 adsorption to octadecyldimethylbenzyl ammonium-modified clinoptilolite-rich zeolitic tuff, Microporous Mesoporous Mater. 105 (2007) 285-290.

[218] A. Dakovic, S. Matijasevic, G.E. Rottinghaus, V. Dondur, T. Pietrass, C.F.M Clewett, Adsorption of zearalenone by organomodified natural zeolitic tuff, J. Colloid Interface Sci. 311 (2007) 8-13.

[219] J. Lemic, D. Kovacevic, M. Tomasevic-Canovic, D. Kovacevic, T. Stanic, R. Pfend Removal of atrazine, lindane and diazinone from water by organo-zeolites, Water Res. 40 (2006) 1079-1085.

[220] D. Krajisnik, A. Dakovic, M. Milojevic, A. Malenovic, M. Kragovic, D.B. Bogdanovic, V. Dondur, J. Milic, Properties of diclofenac sodium sorption onto natural zeolite modified with cetylpyridinium chloride, Colloid Surf. B Biointerfaces 83 (2011) 165-172.

[221] V. Rakic, L. Damjanovic, V. Rac, D. Stosic, V. Dondur, A. Auroux, The adsorption of nicotine from aqueous solutions on different zeolite structures, Water Res. 44 (2010) 2047-2057.

[222] A. Martucci, L. Pasti, N. Marchetti, A. Cavazzini, F. Dondi, A. Alberti, Adsorption of pharmaceuticals from aqueous solutions on synthetic zeolites, Microporous Mesoporous Mater. 148 (2012) 174-183. 
[223] L. Damjanovic, V. Rakic, V. Rac, D. Stosic, A. Auroux, The investigation of phenol removal from aqueous solutions by zeolites as solid adsorbents, J. Hazard. Mater. 184 (2010) 477-484.

[224] V. Jovanovic, V. Dondur, L. Damjanovic, J. Zakrzewska, M. Tomasevic-Canovic, Improved materials for environmental application: Surfactant-modified zeolites, Recent Developments Adv. Mater. Process. 518 (2006) 223-228.

[225] M. Khalid, G. Joly, A. Renaud, P. Magnoux, Removal of phenol from water by adsorption using zeolites, Ind. Eng. Chem. Res. 43 (2004) 5275-5280.

[226] Y. Dong, D.Y. Wu, X.C. Chen, Y. Lin, Adsorption of bisphenol A from water by surfactant-modified zeolite, J. Colloid Interface Sci. 348 (2010) 585-590.

[227] T.S. Jamil, T.A. Gad-Allah, H.S. Ibrahim, T.S. Saleh, Adsorption and isothermal models of atrazine by zeolite prepared from Egyptian kaolin, Solid State Sci. 13 (2011) 198-203.

[228] B. Okolo, C. Park, M.A. Keane, Interaction of phenol and chlorophenols with activated carbon and synthetic zeolites in aqueous media, J. Colloid Interface Sci. 226 (2000) 308-317.

[229] I. Braschi, S. Blasioli, L. Gigli, C.E. Gessa, A. Alberti, A. Martucci, Removal of sulfonamide antibiotics from water: Evidence of adsorption into an organophilic zeolite Y by its structural modifications, J. Hazard. Mater. 178 (2010) 218-225.

[230] S. Karcher, A. Kornmuller, M. Jekel, Screening of commercial sorbents for the removal of reactive dyes, Dyes Pigment. 51 (2001) 111-125.

[231] C.F. Chang, C.Y. Chang, K.H. Chen, W.T. Tsai, J.L. Shie, Y.H. Chen, Adsorption of naphthalene on zeolite from aqueous solution, J. Colloid Interface Sci. 277 (2004) 29-34.

[232] B. Koubaissy, G. Joly, I. Batonneau-Gener, P. Magnoux, Adsorptive removal of aromatic compounds present in wastewater by using dealuminated faujasite zeolite, Ind. Eng. Chem. Res. 50 (2011) 5705-5713.

[233] B. Armagan, M. Turan, M.S. Celik, Equilibrium studies on the adsorption of reactive azo dyes into zeolite, Desalination 170 (2004) 33-39.

[234] R.S. Bowman, Applications of surfactant-modified zeolites to environmental remediation, Microporous Mesoporous Mater. 61 (2003) 43-56.

[235] B. Ersoy, M.S. Celik, Uptake of aniline and nitrobenzene from aqueous solution by organo-zeolite, Environ. Technol. 25 (2004) 341-348.

[236] J.M. Ranck, R.S. Bowman, J.L. Weeber, L.E. Katz, E.J. Sullivan, BTEX removal from produced water using surfactant-modified zeolite, J. Environ. Eng. ASCE 131 (2005) 434-442.

[237] G. Crini, Non-conventional low-cost adsorbents for dye removal: A review, Bioresour. Technol. 97 (2006) 1061-1085.

[238] A. Yalcuk, Removal of phenol from olive mill wastewater in constructed wetlands using different bedding media, Ekoloji 20 (2011) 1-5.

[239] J.Zou, X.S. Guo, Y.P. Han, J.X. Liu, H.W. Liang, Study of a novel vertical flow constructed wetland system with drop aeration for rural wastewater treatment, Water Air Soil Pollut. 223 (2012) 889-900.

[240] A. Yalcuk, N.B. Pakdil, S.Y. Turan, Performance evaluation on the treatment of olive mill waste water in vertical subsurface flow constructed wetlands, Desalination 262 (2010) 209-214.

[241] T. Saeed, G.Z. Sun, Enhanced denitrification and organics removal in hybrid wetland columns: Comparative experiments, Bioresour. Technol. 102 (2011) 967-974.

[242] X.L. Zhang, S. Zhang, F. He, S.P. Cheng, W. Liang, Z.B. Wu, Differentiate performance of eight filter media in vertical flow constructed wetland: Removal of organic matter, nitrogen and phosphorus, Fresenius Environ. Bull. 16 (2007) 1468-1473.

[243] T. Mathialagan, T. Viraraghavan, Adsorption of cadmium from aqueous solutions by perlite, J. Hazard. Mater. 94 (2002) 291-303.

[244] M. Dogan, M. Alkan, A. Turkyilmaz, Y. Ozdemir, Kinetics and mechanism of removal of methylene blue by adsorption onto perlite, J. Hazard. Mater. 109 (2004) 141-148.

[245] B. Acemioglu, Batch kinetic study of sorption of methylene blue by perlite, Chem. Eng. J. 106 (2005) 73-81.

[246] G. Vijayakumar, M. Dharmendirakumar, S. Renganathan, S. Sivanesan, G. Baskar, K.P. Elango, Removal of Congo Red from Aqueous Solutions by Perlite, Clean-Soil Air Water 37 (2009) 355-364.

[247] M. Roulia, A.A. Vassiliadis, Sorption characterization of a cationic dye retained by clays and perlite, Microporous Mesoporous Mater. 116 (2008) 732-740.

[248] M. Alkan, M. Karadas, M. Dogan, O. Demirbas, Adsorption of CTAB onto perlite samples from aqueous solutions, J. Colloid Interface Sci. 291 (2005) 309-318.

[249] M. Aivalioti, I. Vamvasakis, E. Gidarakos, BTEX and MTBE adsorption onto raw and thermally modified diatomite, J. Hazard. Mater. 178 (2010) 136-143.

[250] E. Erdem, G. Çölgeçen, R. Donat, The removal of textile dyes by diatomite earth, J. Colloid Interface Sci. 282 (2005) 314-319.

[251] M.A. Al Ghouti, M.A.M. Khraisheh, S.J. Allen, M.N. Ahmad, The removal of dyes from textile wastewater: a study of the physical characteristics and adsorption mechanisms of diatomaceous earth, J. Environ. Manage. 69 (2003) 229-238.

[252] J. Lin, S. Zhan, M. Fang, X. Qian, The adsorption of dyes from aqueous solution using diatomite, J. Porous Mater. 14 (2007) 449-455.

[253] G.S. Zhang, H.H. Xue, X.J. Tang, F. Peng, C.L. Kang, Adsorption of anionic dyes onto chitosan-modified diatomite, Chem. Res. Chin. Univ. 27 (2011) 1035-1040.

[254] M. Koyuncu, Colour removal from aqueous solution of Tar-Chromium Green 3G dye using natural diatomite, Physicochem. Probl. Mineral Pro. 48 (2012) 485-494.
[255] K. Agdi, A. Bouaid, A.M. Esteban, P.F. Hernando, A Azmani, C. Camara, Removal of atrazine and four organophosphorus pesticides from environmental waters by diatomaceous earth-remediation method, J. Environ. Monit. 2 (2000) 420-423.

[256] B.J. Gao, P.F. Jiang, F.Q. An, S.Y. Zhao, Z. Ge, Studies on the surface modification of diatomite with polyethyleneimine and trapping effect of the modified diatomite for phenol, Appl. Surf. Sci. 250 (2005) 273-279.

[257] W.T. Tsai, C.W. Lai, T.Y. Su, Adsorption of bisphenol-A from aqueous solution onto minerals and carbon adsorbents, J. Hazard. Mater. 134 (2006) 169-175.

[258] J.H. Potgieter, S.O. Bada, S.S. Potgieter-Vermaak, Adsorptive removal of various phenols from water by South African coal fly ash, Water SA 35 (2009) 89-96.

[259] M. Sarkar, P.K. Acharya, Use of fly ash for the removal of phenol and its analogues from contaminated water, Waste Manage. 26 (2006) 559-570.

[260] S. Wang, L. Li, H. Wu, Z.H. Zhu, Unburned carbon as a low-cost adsorbent for treatment of methylene blue-containing wastewater, J. Colloid Interface Sci. 292 (2005) 336-343.

[261] K. Rastogi, J.N. Sahu, B.C. Meikap, M.N. Biswas, Removal of methylene blue from wastewater using fly ash as an adsorbent by hydrocyclone, J. Hazard. Mater. 158 (2008) 531-540

[262] P. Janoš, H. Buchtová, M. Rýznarová, Sorption of dyes from aqueous solutions onto fly ash, Water Res. 37 (2003) 4938-4944.

[263] D. Mohan, K.P. Singh, G. Singh, K. Kumar, Removal of dyes from wastewater using flyash, a low-cost adsorbent, Ind. Eng. Chem. Res. 41 (2002) 3688-3695

[264] N. Singh, Adsorption of herbicides on coal fly ash from aqueous solutions, J. Hazard. Mater. 168 (2009) 233-237.

[265] M.M. Demirkan, A.H. Aydilek, E.A. Seagren, J.C. Hower, Naphthalene and oXylene Adsorption onto High Carbon Fly Ash, J. Environ. Eng. ASCE 137 (2011) 377-387.

[266] R.M. Burgess, S.A. Ryba, M.G. Cantwell, J.L. Gundersen, R. Tien, M.M. Perron, Interaction of planar and nonplanar organic contaminants with coal fly ash: Effects of polar and nonpolar solvent solutions, Environ. Toxicol. Chem. 25 (2006) 2028-2037.

[267] H. Nollet, M. Roels, P. Lutgen, P. Van der Meeren, W. Verstraete, Removal of PCBs from wastewater using fly ash, Chemosphere 53 (2003) 655-665.

[268] M.C. Lu, C.J. Lin, J.M. Chyan, C.H. Liao, Removal of 2,4-dinitrophenol from aqueous solution by coal fly ash, Fresenius Environ. Bull. 14 (2005) 526-530.

[269] V.C. Srivastava, M.M. Swamy, I.D. Mall, B. Prasad, I.M. Mishra, Adsorptive removal of phenol by bagasse fly ash and activated carbon: Equilibrium, kinetics and thermodynamics, Colloid Surf. A Physicochem. Eng. Asp. 272 (2006) 89-104.

[270] K. Banerjee, P.Y. Horng, P.N. Cheremisinoff, M.S. Sheih, L.S. Cheng, Sorption of selected organic pollutants by fly ash, in: Proceedings of the 43rd Industrial Waste Conference, Purdue University, Indiana, USA, 1989, pp. 397-406.

[271] M. Akhtar, S.M. Hasany, M.I. Bhanger, S. Iqbal, Low cost sorbents for the removal of methyl parathion pesticide from aqueous solutions, Chemosphere 66 (2007) 1829-1838.

[272] M. Ahmaruzzaman, V.K. Gupta, Rice husk and its ash as low-cost adsorbents in water and wastewater treatment, Ind. Eng. Chem. Res. 50 (2011) 13589-13613.

[273] D.N. Mbui, P.M. Shiundu, R.M. Ndonye, G.N. Kamau, Adsorption and detection of some phenolic compounds by rice husk ash of Kenyan origin, J. Environ. Monit. 4 (2002) 978-984.

[274] E.A. Korkusuz, M. Beklioglu, G.N. Demirer, Comparison of the treatment performances of blast furnace slag-based and gravel-based vertical flow wetlands operated identically for domestic wastewater treatment in Turkey, Ecol. Eng. 24 (2005) 187-200.

[275] B.Q. Shan, C.M. Hu, W.H. Tang, Y.J. Cheng, Variations in phosphorus speciation in pilot scale subsurface flow wetlands constructed with blast furnace slag and gravel, Clean-Soil Air Water 37 (2009) 818-825.

[276] S.B. He, L. Yan, H.N. Kong, Z.M. Liu, D.Y. Wu, Z.B. Hu, Treatment efficiencies of constructed wetlands for eutrophic landscape river water, Pedosphere 17 (2007) 522-528.

[277] L.H. Cui, Y. Ouyang, Q.A. Lou, F.L. Yang, Y. Chen, W.L. Zhu, S.M. Luo, Removal of nutrients from wastewater with Canna indica L. under different vertical-flow constructed wetland conditions, Ecol. Eng. 36 (2010) 1083-1088.

[278] C.M. Hu, B.Q. Shan, Phosphorus removal performance and mechanisms of a constructed horizontal subsurface flow wetlands treating reclaimed water, Environ. Eng. Sci. 26 (2009) 1097-1106.

[279] E.A. Korkusuz, M. Beklioglu, G.N. Demirer, Use of blast furnace granulated slag as a substrate in vertical flow reed beds: Field application, Bioresour. Technol. 98 (2007) 2089-2101.

[280] B. Gruneberg, J. Kern, Phosphorus retention capacity of iron-ore and blast furnace slag in subsurface flow constructed wetlands, Water Sci. Technol. 44 (2001) 69-75.

[281] A. Bialowiec, W. Janczukowicz, P.F. Randerson, Nitrogen removal from wastewater in vertical flow constructed wetlands containing LWA/gravel layers and reed vegetation, Ecol. Eng. 37 (2011) 897-902.

[282] S. Sousa, P. Jimenez-Guerrero, A. Ruiz, N. Ratola, A. Alves, Organochlorine pesticides removal from wastewater by pine bark adsorption after activated sludge treatment, Environ. Technol. 32 (2011) 673-683.

[283] M. Silva, A. Fernandes, A. Mendes, C.M. Manaia, O.C. Nunes, Preliminary feasibility study for the use of an adsorption/bioregeneration system for molinate removal from effluents, Water Res. 38 (2004) 2677-2684. 
[284] A. Chaparadza, J.M. Hossenlopp, Adsorption kinetics, isotherms and thermodynamics of atrazine removal using a banana peel based sorbent, Water Sci. Technol. 65 (2012) 940-947.

[285] R.K. Sharma, A. Kumar, P.E. Joseph, Removal of atrazine from water by low cost adsorbents derived from agricultural and industrial wastes, Bull. Environ Contam. Toxicol. 80 (2008) 461-464

[286] M.S. Rodriguez-Cruz, M.S. Andrades, A.M. Parada, M.J. Sanchez-Martin, Effect of different wood pretreatments on the sorption-desorption of linuron and metalaxyl by woods, J. Agric. Food Chem. 56 (2008) 7339-7346.

[287] M. Akhtar, S. Iqbal, M.I. Bhanger, M. Moazzam, Utilization of organic byproducts for the removal of organophosphorous pesticide from aqueous media, J. Hazard. Mater. 162 (2009) 703-707.

[288] M. Akhtar, S. Iqbal, M.I. Bhanger, M. Zia-Ul-Haq, M. Moazzam, Sorption of organophosphorous pesticides onto chickpea husk from aqueous solutions, Colloid Surf. B Biointerfaces 69 (2009) 63-70.

[289] V. Domingues, A. Alves, M. Cabral, C. Delerue-Matos, Sorption behaviour of bifenthrin on cork, J. Chromatogr. A 1069 (2005) 127-132.

[290] B.N. Estevinho, N. Ratola, A. Alves, L. Santos, Pentachlorophenol removal from aqueous matrices by sorption with almond shell residues, J. Hazard. Mater. 137 (2006) 1175-1181.

[291] B.N. Estevinho, E. Ribeiro, A. Alves, L. Santos, A preliminary feasibility study for pentachlorophenol column sorption by almond shell residues, Chem. Eng. J. 136 (2008) 188-194.

[292] S.P. Pajooheshfar, M. Saeedi, Adsorptive removal of phenol from contaminated water and wastewater by activated carbon, almond, and walnut shells charcoal, Water Environ. Res. 81 (2009) 641-648.

[293] M. Achak, A. Hafidi, N. Ouazzani, S. Sayadi, L. Mandi, Low cost biosorbent banana peel for the removal of phenolic compounds from olive mil wastewater: Kinetic and equilibrium studies, J. Hazard. Mater. 166 (2009) 117-125.

[294] A.T.M. Din, B.H. Hameed, A.L. Ahmad, Batch adsorption of phenol onto physiochemical-activated coconut shell, J. Hazard. Mater. 161 (2009) 1522-1529.

[295] T. Karbowiak, A.K. Mansfield, V.D. Barrera-Garcia, D. Chassagne, Sorption and diffusion properties of volatile phenols into cork, Food Chem. $122(2010)$ 1089-1094.

[296] C. Duran, D. Ozdes, A. Gundogdu, H.B. Senturk, Kinetics and isotherm analysis of basic dyes adsorption onto almond shell (Prunus dulcis) as a low cost adsorbent, J. Chem. Eng. Data 56 (2011) 2136-2147.

[297] H.B. Senturk, D. Ozdes, C. Duran, Biosorption of Rhodamine 6G from aqueous solutions onto almond shell (Prunus dulcis) as a low cost biosorbent, Desalination 252 (2010) 81-87.

[298] D. Ozdes, A. Gundogdu, C. Duran, H.B. Senturk, Evaluation of adsorption characteristics of malachite green onto almond shell (Prunus dulcis), Sep. Sci. Technol. 45 (2010) 2076-2085.

[299] M. Dogan, H. Abak, M. Alkan, Adsorption of methylene blue onto hazelnut shell: Kinetics, mechanism and activation parameters, J. Hazard. Mater. 164 (2009) 172-181.

[300] F. Ferrero, Dye removal by low cost adsorbents: Hazelnut shells in comparison with wood sawdust, J. Hazard. Mater. 142 (2007) 144-152.

[301] F.D. Ardejani, K. Badii, N.Y. Limaee, S.Z. Shafaei, A.R. Mirhabibi, Adsorption of Direct Red 80 dye from aqueous solution onto almond shells: Effect of $\mathrm{pH}$, initial concentration and shell type, J. Hazard. Mater. 151 (2008) 730-737.
[302] Y.G. Li, B.L. Chen, L.Z. Zhu, Enhanced sorption of polycyclic aromatic hydrocarbons from aqueous solution by modified pine bark, Bioresour. Technol. 101 (2010) 7307-7313.

[303] M.A. Olivella, P. Jove, A. Oliveras, The use of cork waste as a biosorbent for persistent organic pollutants-Study of adsorption/desorption of polycyclic aromatic hydrocarbons, J. Environ. Sci. Health Part A Toxic/Hazard. Subst. Environ. Eng. 46 (2011) 824-832.

[304] E. Nehrenheim, M. Odlare, B. Allard, Retention of 2,4,6-trinitrotoluene and heavy metals from industrial waste water by using the low cost adsorbent pine bark in a batch experiment, Water Sci. Technol. 64 (2011) 2052-2058.

[305] F.G. Braga, S. Pinto, M.C.G. Antunes, Comparative study of 17 beta-estradiol removal from aqueous solutions using pine bark and almond shell as adsorbents, Microchim. Acta 173 (2011) 111-117.

[306] I. Villaescusa, N. Fiol, J. Poch, A. Bianchi, C. Bazzicalupi, Mechanism of paracetamol removal by vegetable wastes: The contribution of $\pi-\pi$ interactions, hydrogen bonding and hydrophobic effect, Desalination 270 (2011) 135-142.

[307] V. Homem, A. Alves, L. Santos, Amoxicillin removal from aqueous matrices by sorption with almond shell ashes, Intern. J. Environ. Anal. Chem. 90 (2010) 1063-1084.

[308] S. Gendrault, R. Bayard, R. Gourdon, Biofiltration onto pine bark for the treatment of water contaminated with atrazine: influence of sorbent on Pseudomonas sp strain adp, Agron. Sustain. Dev. 25 (2005) 317-321.

[309] S.H. Kwon, D. Cho, A comparative, kinetic study on cork and activated carbon biofilters for VOC degradation, J. Ind. Eng. Chem. 15 (2009) 129-135.

[310] R. Wang, N. Korboulewsky, P. Prudent, M. Domeizel, C. Rolando, G. Bonin, Feasibility of using an organic substrate in a wetland system treating sewage sludge: Impact of plant species, Bioresour. Technol. 101 (2010) 51-57.

[311] H.C. Tee, C.E. Seng, A.M. Noor, P.E. Lim, Performance comparison of constructed wetlands with gravel- and rice husk-based media for phenol and nitrogen removal, Sci. Total Environ. 407 (2009) 3563-3571.

[312] S. Sirianuntapiboon, T. Chandanasotthi, P. Sohsalam, M. Rarunroeng, J. Sansak, Application of para-wood charcoal as the media of the vertical-flow constructed wetland for treatment of domestic wastewater, Afr. J. Agr. Res. 2 (2007) 191-199.

[313] R.Y. Wang, N. Korboulewsky, P. Prudent, V. Baldy, G. Bonin, Can verticalflow wetland systems treat high concentrated sludge from a food industry? A mesocosm experiment testing three plant species, Ecol. Eng. 35 (2009) 230-237.

[314] E.K. Putra, R. Pranowo, J. Sunarso, N. Indraswati, S. Ismadji, Performance of activated carbon and bentonite for adsorption of amoxicillin from wastewater: Mechanisms, isotherms and kinetics, Water Res. 43 (2009) 2419-2430.

[315] V.K. Gupta, I. Ali, Suhas, V.K. Saini, Adsorption of 2,4-D and carbofuran pesticides using fertilizer and steel industry wastes, J. Colloid Interface Sci. 299 (2006) 556-563.

[316] A. Bhatnagar, Removal of bromophenols from water using industrial wastes as low cost adsorbents, J. Hazard. Mater. 139 (2007) 93-102.

[317] G.M. Taha, T.M. Mosaed, Blast furnace slag of a ferrosilicon firm in Aswan governorate, upper Egypt, as an adsorbent for the removal of merocyanine dye from its aqueous solution, Chem. Biodivers. 7 (2010) 878-886.

[318] A.K. Jain, V.K. Gupta, A. Bhatnagar, Suhas, Utilization of industrial waste products as adsorbents for the removal of dyes, J. Hazard. Mater. 101 (2003) 31-42.

[319] A. Tor, Y. Cengeloglu, M.E. Aydin, M. Ersoz, Removal of phenol from aqueous phase by using neutralized red mud, J. Colloid Interface Sci. 300 (2006) 498-503. 